\title{
Honey for Wound Healing, Ulcers, and Burns; Data Supporting Its Use in Clinical Practice
}

\author{
Noori S. Al-Waili ${ }^{1,2, *}$, Khelod Salom ${ }^{1}$, and Ahmad A. Al-Ghamdi ${ }^{2}$ \\ ${ }^{1}$ Al-Waili's Foundation for Sciences, Chronic Wound Management and Hyperbaric \\ Medicine, Life Support Technology Group, New York, U.S.A.; ${ }^{2}$ Bee Research Chair, \\ King Saud University, Riyadh, K.S.A. \\ E-mail: noori1966@yahoo.com
}

Received November 20, 2010; Revised March 3, 2011; Accepted March 3, 2011; Published April 5, 2011

The widespread existence of unhealed wounds, ulcers, and burns has a great impact on public health and economy. Many interventions, including new medications and technologies, are being used to help achieve significant wound healing and to eliminate infections. Therefore, to find an intervention that has both therapeutic effect on the healing process and the ability to kill microbes is of great value. Honey is a natural product that has been recently introduced in modern medical practice. Honey's antibacterial properties and its effects on wound healing have been thoroughly investigated. Laboratory studies and clinical trials have shown that honey is an effective broad-spectrum antibacterial agent. This paper reviews data that support the effectiveness of natural honey in wound healing and its ability to sterilize infected wounds. Studies on the therapeutic effects of honey collected in different geographical areas on skin wounds, skin and gastric ulcers, and burns are reviewed and mechanisms of action are discussed. (Ulcers and burns are included as an example of challenging wounds.) The data show that the wound healing properties of honey include stimulation of tissue growth, enhanced epithelialization, and minimized scar formation. These effects are ascribed to honey's acidity, hydrogen peroxide content, osmotic effect, nutritional and antioxidant contents, stimulation of immunity, and to unidentified compounds. Prostaglandins and nitric oxide play a major role in inflammation, microbial killing, and the healing process. Honey was found to lower prostaglandin levels and elevate nitric oxide end products. These properties might help to explain some biological and therapeutic properties of honey, particularly as an antibacterial agent or wound healer. The data presented here demonstrate that honeys from different geographical areas have considerable therapeutic effects on chronic wounds, ulcers, and burns. The results encourage the use of honey in clinical practice as a natural and safe wound healer.

KEYWORDS: honey, wound, ulcer, healing, infection, nitric oxide, prostaglandin 


\section{PATHOPHYSIOLOGY OF WOUND HEALING}

Every year in the U.S., more than 1.25 million people have burns and 6.5 million have chronic skin ulcers caused by pressure, venous stasis, or diabetes mellitus[1]. Diabetes represents a major impact on wound healing outcome. In 2004, according to the World Health Organization (WHO), more than 150 million people worldwide suffered from diabetes. Its incidence is increasing rapidly and it is estimated that by the year 2025, this number will double.

A wound is a disruption of the continuity of a tissue structure. Injury, by surgery or accident, causes destruction of tissue, disruption of blood vessels, and extravasation of blood constituents and hypoxia. Wound healing is a complex, continual process that has three phases: inflammation, a proliferative phase, and tissue remodeling. Basically, wound healing is the result of interactions among cytokines, growth factors, blood and cellular elements, and the extracellular matrix. The cytokines promote healing by various pathways, such as stimulating the production of components of the basement membrane, preventing dehydration, and increasing inflammation and formation of granulation tissue.

At the cellular level, monocytes infiltrate the wound site and become activated macrophages that release growth factors, such as platelet-derived growth factor (PDGF) and vascular endothelial growth factor (VEGF), which initiate the formation of granulation tissue. Macrophages have a key role in inflammation and repair[2]. It has been found that macrophage-depleted animals have defective wound repair[3]. We have found that macrophage transfusion accelerates wound healing in patients with nonhealing wounds[4]. Platelets facilitate the formation of a hemostatic plug and secrete PDGF, which attracts and activates macrophages and fibroblasts[2]. Re-epithelialization of wounds begins shortly after injury. Epidermal cells at the wound margin begin to proliferate within 1 to 2 days after injury. On day 4 after injury, new granulation tissue begins to invade the wound gap and numerous new capillaries grow through the new stroma with its granular appearance. After migrating into wounds, fibroblasts begin the synthesis of the extracellular matrix[2,5].

The induction of angiogenesis was initially attributed to acidic or basic fibroblast growth factors, which are released from macrophages after cell disruption. Angiogenesis is the process of new vessel formation from an existing vasculature network. Once the wound is filled with new granulation tissue, angiogenesis ceases and many of the new blood vessels disintegrate as a result of apoptosis[6]. Wound contraction involves a complex interaction of cells, extracellular matrix, and cytokines.

Vitamins C, E, and A, glucose, amino acids, antioxidants, fatty acids, proteins, water, and zinc are important for wound healing[7,8,9,10,11,12]. Administration of ascorbic acid protected mice against radiation-induced sickness and mortality, and improved healing of wounds after exposure to whole-body gamma radiation[13]. Low levels of antioxidants accompanied by raised levels of markers of free radical damage play a significant role in the delay of wound healing. In diabetic rats, reduced glutathione levels had a role in delaying the healing process[14]. Hydrogen peroxide is one of the mediators of healing responses[15]. Electrolyzed, strong acid aqueous solution irrigation may promote tissue growth in burn wounds[16]. Acidic media enhances wound contraction[7].

Nitric oxide (NO) has a wide range of physiological and pathophysiological activities, including the regulation of vessel tone and angiogenesis in wound healing, inflammation, ischemic cardiovascular diseases, and malignant diseases[17]. NO has been shown to increase microcirculatory blood flow, to kill infective organisms, and to have a significant effect in promoting wound healing[18,19,20,21,22,23]. Prostaglandins are mediators of inflammation and smooth-muscle stimulants, but inhibition of the prostaglandins and their precursors failed to alter the course of wound contraction[24].

Acute or chronic wounds can usually be covered by synthetic or natural dressings. Conservative methods of wound care include the use of standard wound dressings, management of underlying problems (such as hyperglycemia), debridement of dead tissue, restoration of adequate tissue perfusion, limitation of pressure at the wound site, and control of infection. These methods are successful in the majority of patients with acute or chronic skin wounds. However, large and life-threatening skin wounds may require the use of cultured, autologous, epidermal-cell grafts or biologic skin substitutes. 
Recombinant PDGF has been approved by the U.S. Food and Drug Administration (FDA) for the treatment of wounds. Furthermore, topical treatment of wounds is an important aspect of wound care. Proper selection of antiseptic or antimicrobial treatment for contaminated wounds is a cornerstone of wound care. Five commonly used topical agents are 5\% mafenide acetate, $10 \%$ povidone with $1 \%$ free iodine, $0.25 \%$ sodium hypochlorite, $3 \%$ hydrogen peroxide, and $0.25 \%$ acetic acid[25]. In addition, hyaluronic acid was used for wound dressing[26]. Basically, modulation of nutrition, underlining medical problems (such as vascular and neural diseases, diabetes, and infection), acidity of wounds, host immunity, cytokines, NO, or prostaglandins have a great impact on wound healing process.

\section{HEALING PROPERTIES OF HONEY}

Honey has long been documented as having healing properties[27,28,29]. Honey and sugar paste were associated with scarless healing in cavity wounds[30]. It has been reported that rabbit wounds treated with a topical application of honey showed less edema, fewer polymorphonuclear and mononuclear cell infiltrations, less necrosis, better wound contraction, improved epithelialization, and lower glycosaminoglycan and proteoglycan concentrations[31]. Furthermore, honey causes significantly greater wound contraction than controls, and it promotes the formation of granulation tissue and epithelialization of wounds[32,33,34,35,36,37]. Honey stimulates tissue growth, synthesis of collagen, and development of new blood vessels in the bed of wounds[38,39,40,41,42,43]. Intraperitoneal honey administration after an adhesion model in the cecum and terminal ileum of rats reduced postoperative adhesion[44].

\section{HONEY AND WOUNDS}

Generally, wound healing can be affected by endogenous (pathophysiology) and exogenous (microorganisms) factors. The risk of wound infection increases as local conditions favor bacterial invasion and growth. Therefore, microbial colonization of both acute and chronic wounds is inevitable. Many species of bacteria have been recovered from wounds, but Staphylococcus aureus is the most frequently isolated from wound pathogens[45]. In addition, Pseudomonas aeruginosa is an important pathogen in chronic wounds and burns; its presence has been demonstrated in numerous studies and has been found in onethird of chronic leg ulcers[46,47,48,49]. Infection with $S$. aureus and pseudomonads retards ulcer healing rates and, with pseudomonads and B-hemolytic streptococcus, reduces the success of skin grafts used for leg ulcers[50,51].

The widespread development of antibiotic-resistant bacteria is a challenging problem. Therefore, current interest is focused on an alternative to antibiotics and conventional therapies, such as honey, antimicrobial moisture-retentive dressings, essential oils and cationic peptides, topical enzymes, biosurgical therapies, and vacuum therapies. In addition, unregulated inflammation caused by both microorganisms and underlying abnormal pathophysiological conditions is a major factor associated with the process of healing in chronic wounds[52].

Many research works reported the use of honey for treatment of both wounds and infections[53,54,55]. Table 1 summarizes many papers that reported successful use of honey in wound healing. Honey with proven antibacterial activity has the potential to be an effective treatment option for wounds infected or at risk of infection with various human pathogens. The medical literature on treating wounds with honey has been reviewed[56,57,58,59,60,61]. As a dressing on wounds, honey provides a moist healing environment, rapidly clears infection, deodorizes, and reduces inflammation, edema, and exudation. It increases the rate of healing by stimulation of angiogenesis, granulation, and epithelialization[62]. Table 2 demonstrates general effects of honey on the healing process. 
TABLE 1

Effects of Honey on Wounds Healing

\begin{tabular}{|c|c|c|}
\hline $\begin{array}{l}\text { Origin of } \\
\text { Honey }\end{array}$ & Type of Lesion & Effects of Honey \\
\hline $\operatorname{Iran}[31]$ & Surgical incision on rabbits & $\begin{array}{l}\text { Less edema, fewer polymorphonuclear and mononuclear cell } \\
\text { infiltrations, less necrosis, better wound contraction, } \\
\text { improved epithelialization, and lower glycosaminoglycan } \\
\text { and proteoglycan concentrations }\end{array}$ \\
\hline India[39] & $\begin{array}{l}\text { Wounds created on buffalo } \\
\text { calves }\end{array}$ & $\begin{array}{l}\text { Promotes granulation and scar formation, complete healing of } \\
\text { full-thickness wounds occurred faster with honey than with } \\
\text { nitrofurazone or sterilized petrolatum }\end{array}$ \\
\hline India[40] & $\begin{array}{l}\text { Wounds created on buffalo } \\
\text { calves infected with } S . \\
\text { aureus }\end{array}$ & $\begin{array}{l}\text { Faster rate of healing compared with ampicillin ointment and } \\
\text { saline treatments, the least inflammation, the most rapid } \\
\text { fibroblastic and angioblastic activity and epithelialization }\end{array}$ \\
\hline India[42] & $\begin{array}{l}\text { Full-thickness skin wounds } \\
\text { made on back of rats }\end{array}$ & $\begin{array}{l}\text { Increases significantly the quantity of collagen synthesized } \\
\text { and degree of cross-linking of the collagen in the } \\
\text { granulation tissue }\end{array}$ \\
\hline Egypt[64] & Infected diabetic foot wounds & Fast healing and significant decrease of bacterial load \\
\hline Turkey[65] & $\begin{array}{l}\text { Split-thickness skin graft } \\
\text { donor site }\end{array}$ & $\begin{array}{l}\text { Wounds show faster epithelialization time and a low sense of } \\
\text { pain than paraffin gauzes and saline-soaked gauzes }\end{array}$ \\
\hline Turkey[44] & $\begin{array}{l}\text { An adhesion model } \\
\text { constituted in the cecum } \\
\text { and terminal ileum of rats }\end{array}$ & $\begin{array}{l}\text { Intraperitoneal honey administration reduces postoperative } \\
\text { peritoneal adhesion }\end{array}$ \\
\hline Turkey[66] & Intraurethral injury in rats & $\begin{array}{l}\text { Prevents inflammation, accelerates urethral healing, and } \\
\text { provides perfect healing }\end{array}$ \\
\hline $\begin{array}{l}\text { United Arab } \\
\text { Emirates[67] }\end{array}$ & $\begin{array}{l}\text { Injured skin or conjunctiva in } \\
\text { mice or rat }\end{array}$ & Accelerates wound healing and eradicates infection \\
\hline Yemen[68] & Postoperative wound & $\begin{array}{l}\text { Eradicates bacterial infection, accelerates wound healing, } \\
\text { and minimizes scar formation }\end{array}$ \\
\hline Thailand[69] & $\begin{array}{l}\text { Postoperative wound } \\
\text { disruption }\end{array}$ & Complete wound healing within 2 weeks \\
\hline Nepal[71] & $\begin{array}{l}\text { Radiation-induced oral } \\
\text { mucositis }\end{array}$ & Strongly protective against the development of mucositis \\
\hline Nigeria[72] & Wounds and ulcers & $\begin{array}{l}\text { Debrides wounds rapidly, replacing sloughs with granulation } \\
\text { tissue, promotes rapid epithelialization, and absorption of } \\
\text { edema }\end{array}$ \\
\hline Nigeria[73] & Fournier's gangrene & Accelerates wound healing \\
\hline Mexico[33] & Fournier's gangrene & Accelerates wound healing \\
\hline Malawi[76] & $\begin{array}{l}\text { Patients with open or } \\
\text { infected wounds }\end{array}$ & $\begin{array}{l}\text { More effective than sugar in reducing bacterial contamination } \\
\text { and promoting wound healing }\end{array}$ \\
\hline Norway[80] & Chronic wound infection & Eradicates wound bacterial infections and penetrates biofilm \\
\hline Ireland[81] & Nonhealing ulcers & $\begin{array}{l}\text { Manuka honey decreases wound } \mathrm{pH} \text { and causes a reduction } \\
\text { in wound size }\end{array}$ \\
\hline France[82] & Wounds & Accelerates wound healing \\
\hline Germany[84] & $\begin{array}{l}\text { Resistant wound infection in } \\
\text { seven patients }\end{array}$ & Complete wound healing \\
\hline U.K.[85] & Toenail surgery & $\begin{array}{l}\text { Partial avulsion wounds healed faster with paraffin tulle gras } \\
\text { than with the honey dressing }\end{array}$ \\
\hline U.K.[88] & Chronic wounds & Clinical benefits from using honey in wound care \\
\hline U.K.[89] & Meningococcal skin lesions & Helps skin healing \\
\hline Netherlands[91] & $\begin{array}{l}\text { Sixty patients with chronic } \\
\text { wounds }\end{array}$ & $\begin{array}{l}\text { Honey is easy to apply, helpful in cleaning the wounds, and } \\
\text { without side effects }\end{array}$ \\
\hline
\end{tabular}


TABLE 2

General Effects of Honey on Wound Healing

\begin{tabular}{ll}
\hline 1. & Causes greater wound contraction[31,32,33,34,35,36,37,211]) \\
2. & Promotes the formation of granulation tissue[32,33,34,35,36,37,39,92] \\
3. & Promotes epithelialization of wounds[32,33,34,35,36,37,66,73,92] \\
4. & Stimulates tissue growth, synthesis of collagen[38,39,40,41,42,43,92] \\
5. & Stimulates development of new blood vessels in the bed of wounds[38,39,40,41,42,43,62,93] \\
6. & Reduces postoperative adhesion[44] \\
7. & Reduces edema[62,73,92,93] \\
8. & Reduces inflammation[61,62,68,92,93,119] \\
9. & Deodorizes wounds[62,92,93] \\
10. & Promotes moist wound healing[61,92] \\
11. & Facilitates debridement[61,72,93] \\
12. & Reduces pain[66,84,92] \\
\hline
\end{tabular}

Molan[63] published a review article that covered the various reports that have been published on the clinical usage of honey. Positive findings on honey in wound care have been reported from 17 randomized controlled trials (1965 patients) and five clinical trials of other forms (97 patients) treated with honey. On experimental animals, the effectiveness of honey in assisting wound healing has also been demonstrated in 16 trials. There is also a large amount of evidence in the form of case studies[63]. In a recent review aimed to determine whether honey increases the rate of healing in acute wounds (burns, lacerations, other traumatic wounds) and chronic wounds (venous ulcers, arterial ulcers, diabetic ulcers, pressure ulcers, infected surgical wounds), 19 trials $(\mathrm{n}=2554)$ were identified. Conclusively, honey may improve healing times in mild to moderate superficial and partial-thickness burns compared with some conventional dressings. However, honey dressings as an adjuvant to compression do not significantly increase leg ulcer healing at 12 weeks[58]. Another article provides an overview of the use of honey in wound management and reviews the evidence to support its effectiveness in the management of wound healing[59]. Honey has anti-inflammatory and antibacterial effects without antibiotic resistance; it promotes moist wound healing and facilitates debridement. A summary of the current evidence base for the use of honey, a review of its therapeutic effects, and a discussion of the implications for WOC nursing practice was published recently[61]. In the U.S., a honey product received FDA approval in 2007.

In Iran, topical application of honey on wounds created on rabbits showed less edema and necrosis, fewer polymorphonuclear and mononuclear cell infiltrations, better wound contraction, improved epithelialization, and lower glycosaminoglycan and proteoglycan concentrations[31].

In India, a study showed that granulation, scar formation, and complete healing of full-thickness wounds created on buffalo calves occurred faster with honey than with nitrofurazone or sterilized petrolatum[39]. In another study, full-thickness skin wounds were made on buffalo calves after infecting the wound by subcutaneous injections of $S$. aureus 2 days prior to wounding. Topical application of honey, ampicillin ointment, and saline were compared. Honey gave a faster rate of healing compared with ampicillin ointment and saline treatments, the least inflammation, the most rapid fibroblastic and angioblastic activity, and epithelialization[40]. Full-thickness skin wounds made on the backs of rats were treated with topical application of honey to the wound, oral administration of honey, or intraperitoneal administration of honey. Honey increased significantly the quantity of collagen synthesized and degree of cross-linking of the collagen in the granulation tissue. Systemic treatment gave greater increase than topical treatment, while the intraperitoneal route produced better results than the oral route[42]. The thickness of granulation tissue and the distance of epithelialization from the edge of the wound were significantly greater and the area of the wound significantly smaller in wounds treated with honey compared with control when honey was applied on excising skin on the mice down to muscles[43]. 
In Egypt, 30 infected diabetic foot wounds were randomly selected for treatment with clover honey. The honey dressing was applied to wounds for 3 months until healing, grafting, or failure of treatment. Results showed that complete healing was significantly achieved in $43.3 \%$ of ulcers, and decrease in size and healthy granulation was significantly observed in another $43.3 \%$ of patients. After 1 week, bacterial load of all ulcers was significantly reduced. The authors reported that commercial clover honey is a clinical and cost-effective dressing for diabetic wounds in developing countries[64].

From Turkey, for the treatment of a split-thickness skin graft donor site, honey-impregnated gauze showed faster epithelialization time and a lower sense of pain than paraffin gauzes and saline-soaked gauzes[65]. Another study was performed to evaluate the effect of honey applied intraurethrally after urethral injury on histopathological healing in male rats. Results showed that intraurethral honey, applied after urethral injury, prevents inflammation and accelerates urethral healing[66]. A study has shown that intraperitoneal honey administration reduces postoperative peritoneal adhesion; the wound healing accelerative effect and the mechanical barrier formed by the honey was explained to be the reasons for its inhibitory effect on the adhesion[44].

From the United Arab Emirates, Al-Waili found that topical application of multifloral honey on wounds infected with various human pathogens inoculated onto injured skin or conjuctiva in mice and rats accelerates wound healing and eradicates bacterial infections[67]. Al-Waili and Salom have reported that multifloral honey collected from Yemen applied to postoperative wound infections could eradicate bacterial infections, accelerate wound healing, and minimize scar formation[68].

In Thailand, the usefulness of honey application as an alternative method of managing abdominal wound disruption was assessed. Fifteen patients whose wounds disrupted after caesarean section were treated with honey application and wound approximation by Micropore ${ }^{\mathrm{TM}}$ tape instead of the traditional method of wound dressing with subsequent resuturing. Within 2 weeks, an excellent result was achieved in all the cases with complete healing[69].

In Israel, nine infants with large, open, infected wounds that failed to heal with conventional treatment were treated with honey. All infants showed marked clinical improvement after 5 days of treatment with topical application of 5-10 $\mathrm{ml}$ of honey twice daily[70].

Another study from Nepal investigated whether honey's anti-inflammatory properties might limit the severity of radiation-induced oral mucositis. A single-blinded, randomized, controlled clinical trial was carried out to compare the mucositis-limiting qualities of honey with lignocaine. It was found that honey is strongly protective against the development of mucositis. The authors concluded that honey applied topically to the oral mucosa of patients undergoing radiation therapy appears to provide a considerable benefit by limiting the severity of mucositis[71].

In Nigeria, 59 patients with wounds and ulcers, most of which had failed to heal with conventional treatment, were treated with unprocessed honey. Fifty-eight cases showed remarkable improvement following topical application of honey. Honey debrided wounds rapidly, replacing sloughs with granulation tissue. It also promoted rapid epithelialization and absorption of edema from around the ulcer margins[72]. In another study from Nigeria, 20 consecutive cases of Fournier's gangrene managed conservatively with systemic antibiotics and topical application of honey were compared retrospectively with 21 similar cases managed by wound debridement and excision[73]. Honey has been compared with phenytoin in a prospective randomized controlled trial on chronic leg ulcers[74]. Two groups of 25 patients with ulcers were involved, with a mean duration of 56.5 months. There was no significant difference found in the rate of healing between the honey and phenytoin treatments.

In Burundi, 40 patients with wounds of various origins were treated with topical honey, which provided healing in $88 \%$ of the cases[75]. In Mexico, 38 patients with Fournier's gangrene were treated with antimicrobial therapy, broad debridement, and application of unprocessed honey dressings. Patients then underwent split-thickness skin grafts or delayed closure as needed. It was found that topical application of honey is beneficial to the healing process[33]. Results showed that topical application of honey was better than conventional methods. Three deaths occurred in the orthodox method, whereas no deaths occurred in those treated with honey. 
In Malawi, to investigate whether there is a difference between the efficacy of honey and sugar as wound dressings, patients with open or infected wounds were randomized to receive either honey or sugar dressings. Forty patients were enrolled. In the honey group, $55 \%$ of patients had positive wound cultures at the start of treatment and $23 \%$ at 1 week, compared with 52 and 39\%, respectively, in the sugar group. Honey was more effective than sugar in reducing bacterial contamination and promoting wound healing, and was slightly less painful than sugar during dressing changes[76].

From South Africa, the effects of silver- and honey-based dressings on cell viability (keratinocyte cultures) were compared. Results showed that there was no significant difference between the best performing silver- and honey-based wound preparations with regard to cell viability[77]. Another study from the same area was planned to establish whether honey (L-Mesitran $\left.{ }^{\circledR}\right)$ and silver-impregnated dressings are cytotoxic in vitro to human skin keratinocytes and dermal fibroblasts. In cultures with honey-impregnated implants, cell viability remained intact and cell toxicity was not evident at 4 months after continuous tissue culture. In cultures with nanocrystalline silver, marked toxicity was observed with high nonviability staining and cell-scoring counts. The honey-based product showed excellent cytocompatibility with tissue cell cultures compared with the silver dressing[78]. Furthermore, it was found that there was no evidence of a real difference between honey and IntraSite ${ }^{\mathrm{TM}}$ Gel as healing agents. It was concluded that honey is a safe, satisfying, and effective healing agent and is cost effective[79].

In Norway, the effects of different concentrations of Medihoney ${ }^{\mathrm{TM}}$ therapeutic honey and Norwegian Forest Honey (1) on the real-time growth of typical chronic wound bacteria, (2) on biofilm formation, and (3) on the same bacteria already embedded in biofilm were studied. Reference strains of MRSE, MRSA, ESBL Klebsiella pneumonia, and $P$. aeruginosa were incubated with dilution series of the honeys in microtiter plates for $20 \mathrm{~h}$. It was found that both honeys were bactericidal against all the strains of bacteria. Biofilm was penetrated by biocidal substances in the honey[80]. In Ireland, a study was conducted to analyze the changes in surface $\mathrm{pH}$ and size of nonhealing ulcers following application of manuka honey dressing. Reduction in wound $\mathrm{pH}$ after 2 weeks was statistically significant. Wounds with $\mathrm{pH} \geq 8.0$ did not decrease in size and wounds with $\mathrm{pH} \leq 7.6$ had a $30 \%$ decrease in size. The use of manuka honey dressings was associated with a statistically significant decrease in wound $\mathrm{pH}$ and a reduction in wound size[81].

In France, 40 patients with wounds of various etiology - surgical, accidental, infective, trophic, and burns - were treated with topical application of honey. Of the 33 patients treated only with honey dressing, 29 patients healed successfully. Honey delimited the boundaries of the wounds and cleansed them rapidly[82].

In Sweden, when commercial unboiled honey was applied topically to open wounds in mice, the wounds of the honey-treated animals healed much faster than the wounds of the control animals[43].

In Poland, the case of a 55-year-old woman with extensive phlegmonous and necrotic lesions of the abdominal integuments and the lumbar area following traumatic colonic rupture, treated with manuka honey wound dressings and the GENADYNE A4 negative pressure wound healing system, was discussed. The results showed that this intervention brought good effects, ultimately enabling skin autografting on the wound site and complete wound healing[83].

In Germany, full healing was achieved in seven patients whose wounds were either infected or colonized with MRSA. Antiseptics and antibiotics had previously failed to eradicate the clinical signs of infection[84].

In the U.K., honey-impregnated dressings successfully were used in the wound care clinic and on the maxillofacial ward[85]. A double-blind, randomized controlled trial investigated the effect of a honey dressing on wound healing following toenail surgery with matrix phenolization. One hundred patients were randomly assigned to receive either an active manuka honey dressing or paraffin-impregnated tulle gras. Mean healing times were 40.30 days for the honey group and 39.98 days for the paraffin tulle gras group. Partial avulsion wounds healed statistically significantly faster with paraffin tulle gras than with the honey dressing[86]. In another report, a case study explored the healing of a chronic wound (20 years' duration) in a patient with dystrophic epidermolysis bullosa with use of a honey-impregnated dressing; 
the wounds were not responding to different dressings and creams[87]. Another study from the U.K. that was conducted to compare a medical-grade honey with conventional treatments on the healing rates of wounds healing by secondary intention included 105 patients who were involved in a single-center, openlabel, randomized controlled trial in which patients received either a conventional wound dressing or honey. The median time to healing in the honey group was 100 days compared with 140 days in the control group. The authors concluded that there are clinical benefits from using honey in wound care[88]. Chronic infected meningogococcal skin lesions were successfully treated with honey[89]. In another study from the same country, manuka honey was found to eradicate MRSA in a hydroxyurea-induced leg ulcer developed in an immunosuppressed patient; rapid healing was successfully achieved[90].

In the Netherlands, authors evaluated the use and safety of a honey-medicated dressing in a feasibility (phase II) study featuring 60 patients with chronic, complicated, surgical, or acute traumatic wounds. In all but one patient, honey was found easy to apply, helpful in cleaning the wounds, and without side effects[91].

Generally, it has been shown that topical honey possesses antimicrobial properties, promotes autolytic debridement, stimulates growth of wound tissues to hasten healing and to start the healing process in dormant wounds, stimulating anti-inflammatory activity that rapidly reduces pain, edema, and exudate production[92]. Patients with recalcitrant wounds and ulcers, including Fournier's gangrene, burns, cancrum oris and diabetic ulcers, decubitus, sickle-cell and tropical ulcers, were successfully treated with topical honey application; all had been treated for a long time with conventional treatment with no signs of healing or with the wounds increasing in size[93]. Basically, there have been many reports of case studies, animal experiments, and randomized controlled trials that provide considerable evidence for the effectiveness of honey in wound healing. As a dressing on wounds, honey provides a moist healing environment, rapidly clears infection, deodorizes, and reduces inflammation, edema, and exudation.

\section{HONEY AND SKIN ULCERS}

Honey has been used in the treatment of ulcers due to various etiologies[42,94,95,96,97,98,99,100,101]. In a review of the literature, more than 470 cases were treated with honey; there were only five cases where successful healing was not achieved[102]. In another review study, the authors summarized evidence of honey's effectiveness, its hypothesized mechanism of action, potential risks and benefits, the types of honey available, and the nature of its application. Critical aspects of ulcer care are also reviewed. It was concluded that honey is a low-cost topical therapy with important potential for healing[103]. The use of honey in two patients with pressure ulcers resulted in a rapid and complete healing of both wounds. The antibacterial activity of honey had a deodorizing effect on the wounds and its anti-inflammatory actions reduced the level of pain[95]. Further, honey was used successfully for necrotizing breast ulcer management[101]. Out of 59 treated patients with wounds and ulcers, 58 patients showed remarkable improvement following topical application of honey; sloughs, necrotic, and gangrenous tissue separated and could thus be lifted off painlessly[73].

In the U.K., three patients with chronic leg ulceration were assessed as potentially benefiting from the action of medical honey to achieve wound healing. The etiology of ulceration in patient 1 was mixed arterial and venous, and in patients 2 and 3, venous. All had several years' history of recurrence. Promotion of healing occurred in all the cases, with a reduction in the incidence of infection, reduction in pain, and the provision of comfort[104]. In Malaysia, authors carried out a prospective study to compare the effect of honey dressing for 30 Wagner's grade-II diabetic foot ulcers with a controlled dressing group (povidone iodine followed by normal saline). Surgical debridement and appropriate antibiotics were prescribed for all patients. The mean healing time in the standard dressing group was 15.4 days compared to 14.4 days in the honey group; ulcer healing was not significantly different in both study groups. It was concluded that honey dressing is a safe, alternative dressing for Wagner's grade-II diabetic foot ulcers[105]. In another study, 40 patients whose leg ulcers had not responded to 12 weeks of compression 
therapy were recruited. Medihoney dressings were applied on their ulcers for the 12 -week study period; ulcer pain and size decreased significantly and odorous wounds were deodorized promptly[106].

In Ireland, a study was done to determine the qualitative bacteriological changes that occurred during a 4-week treatment period with either manuka honey or a hydrogel dressing; 108 patients enrolled in the study. At baseline, MRSA was identified in 16 wounds (10 in the honey group vs. six in the hydrogel group). Results showed that manuka honey was effective in eradicating MRSA from $70 \%$ of chronic venous ulcers. The potential to prevent infection is increased when wounds are desloughed and MRSA is eliminated[107]. In another report, three males and five females with leg ulceration of different etiologies were treated with honey. The wounds were dressed weekly with manuka honey. The size of the ulcers was significantly reduced, the odor was eliminated, and the pain was relieved. The authors concluded that the use of manuka honey was associated with a positive wound healing outcome[108].

In Turkey, a 5-week, randomized clinical trial evaluated the effect of a honey dressing on pressure ulcer healing, and comparison with an ethoxy-diaminoacridine plus nitrofurazone dressing was conducted. Thirty-six patients with a total of 68 stage II or III pressure were enrolled in the study. After 5 weeks of treatment, patients who were treated by honey dressing had significantly better PUSH tool scores than subjects treated with the ethoxy-diaminoacridine plus nitrofurazone dressing[109].

In Pakistan, a study was carried out to export the results of topical wound dressings in diabetic wounds with natural honey. Initially, all wounds were washed thoroughly, necrotic tissues were removed, and dressings with honey were applied. The study demonstrated excellent results in treating diabetic wounds with dressings soaked with natural honey. The disability of diabetic foot patients was minimized by decreasing the rate of leg or foot amputations and, thus, enhancing the quality and productivity of individual life[110].

Contrary to previous works, a community-based, open-label, randomized trial allocated people with venous ulcers to calcium alginate dressings impregnated with manuka honey or usual care. Of 368 participants, 187 were randomized to honey and 181 to usual care. At 12 weeks, 104 ulcers in the honeytreated group and 90 in the usual care group had healed. The authors stated that the treatment with honey was probably more expensive and associated with more adverse events. It was concluded that honeyimpregnated dressings did not significantly improve venous ulcer healing at 12 weeks compared with usual care[111]. In Nigeria, the efficacy of locally applied natural honey was compared to that of Eusol solution in an open trial involving 20 patients with sickle cell anemia who were in steady clinical states and had chronic leg ulceration. Eleven ulcers were dressed with honey, while eight were dressed with Eusol. No significant differences were found in the rates of healing of the ulcers in either treatment groups[112].

\section{HONEY AND BURNS}

Burn injuries are associated with a high incidence of death and disability. Advances in cellular biology, and knowledge in wound healing and growth factors, have helped to move steps toward burn management. Split-thickness skin grafting with autografts is the standard of care. Honey was used for management of burns and the use of honey for burns has been reviewed[113,114,115,116,117,118]. Various modalities have been reviewed, including honey, human amnion, xenograft, allograft, cultured epithelial autograft, and various engineered commercial products, for use in the biologic treatment of burn wounds[116]. A systematic review and meta-analysis of randomized controlled trials that compared the efficacy of honey with a comparator dressing treatment in the management of burns was conducted. Eight studies with 624 subjects were included. It was found that in most studies, honey covered by sterile gauze was compared with silver sulfadiazine-impregnated gauze. The fixed effects odds ratio for healing at 15 days was 6.1 (95\% CI 3.7-9.9) in favor of honey having a superior effect. The secondary outcome variables all showed significantly greater efficacy for honey treatment. It was concluded that available evidence indicates markedly greater efficacy of honey compared with alternative dressing treatments for superficial or partial-thickness burns[118]. 
In the U.K., a review study aimed to investigate topical honey for superficial burns through a systematic review of randomized controlled trials. Five studies in patients with partial-thickness or superficial burns involving $<40 \%$ of the body surface were reviewed. Comparators were polyurethane film, amniotic membrane, potato peel, and silver sulfadiazine. The number needed to treat for 7 days with honey to produce one patient with a healed burn was 2.6 (2.1-3.4) compared with any other treatment, and 2.7 (2.0-4.1) compared with potato peel and amniotic membrane. For most of the outcomes, honey was superior to all other treatments. In addition, time for healing was significantly shorter for honey than other treatments[117]. In France, it was found that healing was rapid for first- and second-degree burns[119]. Honey produced attenuation of inflammation and exudation, plus rapid regeneration of outer epithelial tissue and cicatrization. In the Netherlands, honey-treated burns showed less inflammation than those treated with sugar and silver sulfadiazine[120].

In Malaysia, full-thickness burn wounds created on the dorsum of 36 rats were inoculated with $P$. aeruginosa, K. pneumoniae, or Acinetobacter baumannii. The wounds were dressed with tualang honey, hydrofiber, and hydrofiber silver. Results showed that there was a rapid reduction in wound size by day 6 in the tualang honey-treated wounds. Tualang honey-treated rats demonstrated a reduction in bacterial growth in $P$. aeruginosa-inoculated wounds. However, hydrofiber silver- and hydrofiber-treated wounds are superior to honey-treated wounds with A. baumannii[121]. Antibacterial activity of Aquacel-tualang honey, Aquacel-manuka honey, Aquacel-Ag, and Aquacel-plain dressings against bacteria isolated from burn patients were tested in vitro. Seven organisms were isolated: Enterobacter cloacae, K. pneumoniae, Pseudomonas spp., Acinetobacter spp., S. aureus, coagulase-negative S. aureus, and Streptococcus spp. Aquacel-Ag and Aquacel-manuka honey dressings gave a better zone of inhibition for Gram-positive bacteria compared to the Aquacel-tualang honey dressing. However, comparable results were obtained against Gram-negative bacteria tested with Aquacel-manuka honey and Aquacel-tualang honey dressings. Tualang honey has a bactericidal as well as bacteriostatic effect[122].

In Pakistan, in a randomized, comparative clinical trial, the efficacy of honey for the treatment of superficial and partial-thickness burns covering $<40 \%$ of body surface area was evaluated in 150 patients and compared its results with those of silver sulfadiazine. The rate of re-epithelialization and healing of superficial and partial-thickness burns was significantly faster in the sites treated with honey than in the sites treated with silver sulfadiazine. Six patients had positive culture for $P$. aeruginosa in the honeytreated site, whereas 27 patients had positive culture in the silver sulfadiazine-treated site[123].

Another study was carried out in Iran to compare the effect of honey and mafenide acetate on auricular burn in rabbits. Results showed that although the pathologic score of the honey group was better than that of the mafenide group, both on 14 and 21 days after burning, it was not statistically significant. In the mafenide acetate group, deep complication of burn (chondritis) was significantly lower than that of the honey group[124].

In Turkey, a study evaluated honey use for the split-thickness skin graft fixation because of its adhesive and other beneficial effects in 11 patients. No complications, such as graft loss, infection, or graft rejection, were reported[125].

In India, a prospective, randomized clinical study to compare honey-impregnated gauze with amniotic membrane dressing in partial-thickness burns was performed. Sixty-four patients were studied; 40 were treated with honey-impregnated gauze and 24 were treated with amniotic membrane. The burns treated with honey healed earlier as compared to those treated with the amniotic membrane (mean 9.4 vs. 17.5 days). Residual scars were noted in $8 \%$ of patients treated with honey-impregnated gauze and in $16.6 \%$ of cases treated with amniotic membrane[126]. In another study, 104 cases of superficial burn injury were treated with honey as a dressing or with silver sulfadiazine gauze dressing. In the 52 patients treated with honey, $91 \%$ of wounds were rendered sterile within 7 days. In the 52 patients treated with silver sulfadiazine, $7 \%$ showed control of infection within 7 days. In addition, healthy granulation tissue was observed earlier in patients treated with honey, and of the wounds treated with honey, $87 \%$ healed within 15 days as compared to $10 \%$ in the control group[113]. In India, the effect of honey dressing and silver sulfadiazine dressing on wound healing in burn patients was studied in 78 patients with first- and seconddegree burns of $<50 \%$ of total body surface area. Honey dressings improved wound healing, made the 
wound sterile in less time, had a better outcome in terms of prevention of hypertrophic scarring and postburn contractures, and decreased the need of debridement irrespective of time of admission, when compared to silver sulfadiazine dressings[127].

Twenty-five patients with burns were randomly allocated for treatment with honey or silver sulfadiazine. Of the wounds treated with honey, $84 \%$ showed satisfactory epithelialization by the 7 th day and $100 \%$ of the patients by the 21 st day. In addition, in honey-dressed wounds, early subsidence of acute inflammatory changes, better control of infection, and quicker wound healing was observed[38]. Honeyimpregnated gauze was compared with OpSite ${ }^{\mathrm{TM}}$ as a cover for fresh, partial-thickness burns in two groups of 46 randomly allocated patients. Results showed that wounds dressed with honey-impregnated gauze showed earlier healing as compared those dressed with OpSite[127].

\section{HONEY AND WOUND DRESSING}

Honey has been used for its healing properties for centuries and has been used to dress wounds with promising results. Honey dressings increase healing, minimize debridement, prompt successful graft, remove dry crust, prevent dry scab formation on burns, cleanse wounds, ease separation of sloughs, deodorize wounds, cause soothing of wounds, and minimize scar formation[33,38,41,73,75, $126,127,128,129,130,131]$. Honey dressings are easy to apply and remove[73,128,129,130,131,132]. The use of honey as a wound dressing was reviewed recently[133].

Honey has antibacterial activity and, consequently, it is effective in treating infected wounds $[43,44,45,46,47,48,49,50,51,52,53,54,55,56,57,58,59,60,61,62,63,64,65,66,67,68,69,70,71,72,76$, $77,132,134,135,136,137,138,139,140,141,142,143,144,145,146,147,148,149,150]$. Clinical studies on the use of honey as a dressing for infected wounds report that the wounds become sterilized in 3-10 days[100,101,102]. Al-Waili and Salom have used honey dressings for treatment of postoperative caesarean section wound infections[68]. Honey applied to the wounds after washing with normal saline and covered with dry gauze reduced healing time and hospital stay, promoted fast eradication of bacterial infection, prevented wound dehiscence, and caused minimal scar formation. Honey could act as a barrier, which would prevent wound infection[38,72,132]. In clinical practice, honey is spread on the wound, then covered with dry gauze[38,69,75]. In case of abscess or necrotic tissue, honey is applied after drainage of abscess or removal of necrotic tissues[33,151].

\section{MECHANISMS OF ACTION}

Wound infection is an important factor that delays or inhibits wound healing. Wound healing needs a good healthy environment so that the normal physiological process will result in a normal healing process with minimal scar formation. One of the most important strategies to keep the process of healing ongoing is to sterilize damaged tissue from any microbial infection. Honey has many effects, such as antibacterial, antioxidant, antitumor, anti-inflammatory, and various metabolic effects. Regarding antibacterial activity, inhibition of bacterial growth has been shown using impregnated honey disks or incorporating honey into agar plates[152]. How much of this inhibition is due to honey's antimicrobial properties or to its acidity and hyperosmolar nature is not well established[152]. In this regard, the hyperosmolar sugar paste also has antibacterial activity and is superior to antiseptics[153]. Various studies explore that honey has beneficial effects on wound healing apart from its antibacterial properties. The accelerative effect of honey in the wound healing process is related to its physical properties of hygroscopicity, hypertonicity, lower $\mathrm{pH}$, and complex chemical composition. However, the stimulatory effects obtained when honey was administered orally or parenterally suggest that a tissue growth factor may be involved, rather than stimulation of growth being a consequence of wound acidification or improved nutrition of the tissue. 


\section{Hydrogen Peroxide}

Hydrogen peroxide $\left(\mathrm{H}_{2} \mathrm{O}_{2}\right)$ is important as an antiseptic and stimulates the wound healing process. Recent work using zebrafish reveals a novel mechanism of early leukocyte recruitment to wounds through a concentration gradient of $\mathrm{H}_{2} \mathrm{O}_{2}$ [154]. Neutrophils release bactericidal reactive oxygen species and $\mathrm{H}_{2} \mathrm{O}_{2}$ to kill bacteria and prevent infection. Macrophages arrive at the wound in response to environmental stimuli and release VEGF, an angiogenic factor crucial for wound healing. $\mathrm{H}_{2} \mathrm{O}_{2}$ increases macrophage VEGF through an oxidant induction of the VEGF promoter. This oxidant stimulation can be mediated by activated neutrophils[155].

It has been assumed that the antibacterial activity of honey is due to $\mathrm{H}_{2} \mathrm{O}_{2}$ [156]. $\mathrm{H}_{2} \mathrm{O}_{2}$ is an oxidizing agent released by the action of the enzyme oxidase that is added by bees to nectar[156]. Much of the literature indicates that rates of $\mathrm{H}_{2} \mathrm{O}_{2}$ production by glucose oxidase in honey vary greatly and increase disproportionately with different degrees of honey dilution[157,158,159,160]. $\mathrm{H}_{2} \mathrm{O}_{2}$ is generated on dilution of honey[161]. The concentration of $\mathrm{H}_{2} \mathrm{O}_{2}$ produced in honey is about 1000 times less than in the $3 \%$ solution commonly used as an antiseptic[56]. The rate of $\mathrm{H}_{2} \mathrm{O}_{2}$ production per milliliter of honey solution decreased at higher honey concentrations[162]. When honey and sugar are used as dressings, they become diluted[163]. $\mathrm{H}_{2} \mathrm{O}_{2}$ has been reported to stimulate fibroblast proliferation in vitro and angiogenesis in vivo[164]. Interestingly, honey has high levels of antioxidants that would protect wound tissues from oxygen radicals that may be produced by $\mathrm{H}_{2} \mathrm{O}_{2}[165]$.

In Canada, it was suggested that the antimicrobial activity in some honeys depends on the endogenous $\mathrm{H}_{2} \mathrm{O}_{2}$ content. The study was aimed to determine whether honey's $\mathrm{H}_{2} \mathrm{O}_{2}$ level could serve as a honey-specific, activity-associated biomarker that would allow the prediction and assessment of the therapeutic effects of honey. Using a broth microdilution assay, antibacterial activities of 42 Canadian honeys against two bacterial strains, Escherichia coli (ATCC 14948) and Bacillus subtilis (ATCC 6633), were analyzed. The results show that all Canadian honeys exhibited antibacterial activity, with higher selectivity against $E$. coli than $B$. subtilis, and that these antibacterial activities were correlated with $\mathrm{H}_{2} \mathrm{O}_{2}$ production in honey[166]. Obviously, $\mathrm{H}_{2} \mathrm{O}_{2}$ generated from honey application could help to control wound infection as well as to help wound healing.

\section{Osmolarity}

It was found that solutions of high osmolarity, such as honey, glucose, and sugar pastes, inhibit microbial growth because the sugar molecules tie up water molecules so that bacteria have insufficient water to grow[163]. Therefore, high osmolarity is valuable in the treatment of infections because it prevents the growth of bacteria and encourages healing[153]. Sugar was used to enhance wound healing for several hundred patients[167]. It has been claimed that the sugar content of honey is responsible for its antibacterial activity, which is due entirely to the osmotic effect of its high sugar content $[98,132,168,169]$. High osmolarity can safely be achieved topically by the use of sugar paste or honey.

\section{Nonperoxide Activity and Antioxidants}

It was found that antibacterial activity persist in honeys treated with catalase to remove the $\mathrm{H}_{2} \mathrm{O}_{2}$ activity[170,171,172,173]. Manuka honey was found to have an exceptionally high level of nonperoxide antibacterial activity[173]. Some floral sources provide additional antibacterial components by way of plant-derived chemicals in the nectar, such as flavonoids and aromatic acids[150]. Oxygen radicals are involved in various aspects of inflammation. Free radicals cause inflammation and damage to tissue[174,175,176,177,178]. The application of antioxidants to burns has been shown to reduce inflammation[1]. Honey inactivates the free iron, which catalyzes the formation of oxygen free radicals 
produced by $\mathrm{H}_{2} \mathrm{O}_{2}$, and its antioxidant components help to mop up oxygen free radicals[165,179]. Darker honeys were more inhibitory than light-colored honeys. Since antimicrobial activity of the darker honeys was not eliminated by catalase, nonperoxide components, such as antioxidants, may contribute to controlling the growth of some food-borne pathogens[150].

\section{Physical Properties}

The physical properties of honey provide a protective barrier and, by osmosis, create a moist wound healing environment that does not stick to the underlying wound tissues.

\section{Increased Lymphocytic and Phagocytic Activity}

In the U.K., a study was carried out to investigate the effect of each of three honeys (manuka, pasture, and jelly bush) on the release of inflammatory cytokines from MM6 cells. These honeys, together with a sugar syrup control (artificial honey), were incubated with MM6 cells. All honeys significantly increased the TNF- $\alpha$, IL-1 $\beta$, and IL-6 release from MM6 cells (and human monocytes) when compared with untreated and artificial honey-treated cells. Jelly bush honey significantly induced the maximal release of each cytokine compared with manuka, pasture, or artificial honeys. These results suggest that the effect of honey on wound healing may in part be related to the stimulation of inflammatory cytokines from monocytic cells. Such cell types are known to play an important role in healing and tissue repair[180]. Honey stimulates proliferation and activation of peripheral blood B and T lymphocytes in cell culture. Jungle honey was found to enhance the immune system and possess chemotactic activity for neutrophils having antitumor activity; the effective immune component of jungle honey is substrate of molecular weight 261[181].

\section{Acidity}

Chronic nonhealing wounds have an elevated alkaline environment. Lowering the wound $\mathrm{pH}$ can potentially reduce protease activity, increase fibroblast activity, and increase oxygen release, consequently aiding wound healing. The glucose content of honey and the acid $\mathrm{pH}$ may assist in the bacterial-killing action of macrophages[182]. We have found that honey activity increased in acidic media[68]. However, the antibacterial activity was not significantly suppressed upon neutralization of its acidity[68]. In addition, many bacteria and fungi can survive or resist acidic media and can tolerate extremely acidic conditions[183,184,185,186,187]. Therefore, as we previously demonstrated, the acidity of honey could not be a sole factor for its antibacterial activity[68].

In Ireland, a study was conducted to analyze the changes in surface $\mathrm{pH}$ and size of nonhealing ulcers following application of a manuka honey dressing after 2 weeks. Wounds with $\mathrm{pH} \geq 8.0$ did not decrease in size and wounds with $\mathrm{pH} \leq 7.6$ had a $30 \%$ decrease in size. The use of manuka honey dressings was associated with a statistically significant decrease in wound $\mathrm{pH}$ and a reduction in wound size[82]. It was found that topical acidification of experimental deep partial-thickness burns promoted healing[188].Therefore, honey acidity might help wound healing.

\section{Nitric Oxide}

NO is important for healing, bacterial killing, viral inhibition, immunological response, and respiratory, renal, cardiovascular, and nervous systems functions. Investigators have implicated NO in the inflammatory and proliferative phases of wound healing[189]. Wound healing involves platelet, 
inflammatory cell, fibroblast, and epithelial cells; all of them are capable of producing NO[190]. NO can reverse impaired healing in diabetic patients[191]. Moreover, NO can enhance bone healing, and it inhibits tumor growth and metastasis[192,193].

It has been shown that NO plays a role in the host defense against various infections[191]. Killing of intracellular pathogens is mediated by $\mathrm{NO}$ [192]. Replication of many viruses can be inhibited by $\mathrm{NO}$ [194]. It was found that NO is a very important mediator of immune responses and could prevent skin damage induced by UVB[194,195]. We have found that honey contains NO end products[196]. In addition, honey increases NO end products in various biological fluids, such as urine, saliva, and plasma[197,198]. Intravenous honey increased NO end products in plasma and urine[196]. We have found that antimicrobial activity of honey was decreased by exposure to heating and prolong storage[68]. Heating and prolonged storage decreased NO metabolites identified in various kinds of honey. In addition, the concentration of NO metabolites varies in various types of honey. This might help to explain the fact that the antimicrobial activity of honey varies markedly with its origin[199]. Furthermore, it was suggested that many effects of honey on immunity, bacterial infections, and wound healing could be explained by the ability of honey to increase NO production[196,197,198].

\section{Prostaglandins}

Prostaglandins are mediators of inflammation and pain. They are widely regarded as immunosuppressive, which can decrease many aspects of B- and T-lymphocyte functions[200]. They are effective in inhibiting antibody production by B lymphocytes and they increased the induction of a specific $\mathrm{T}$ suppressor[201,202]. Prostaglandins reduce immunity and play a critical role in cancer development[203].

Dr. Al-Waili was the first who reported the immunosuppressive effects of prostaglandins on antibody production and, consequently, prostaglandin synthesis inhibitors used to combat tumors and increase immunity[204,205,206,207]. In addition, prostaglandins change serum protein components during antigen stimulation[208]. We have found that honey can lower plasma prostaglandin concentrations in normal individuals[209]. Its inhibitory effect was increased with time. The site of actions could be either at COX1 or COX-2, or both. Recently, it was found that artificial honey made of glucose and fructose increased prostaglandin concentrations[209]. Therefore, natural honey might contain raw materials that are capable of inhibiting prostaglandin synthesis[209]. The ability of honey to lower prostaglandin concentrations could explain many of its biological and therapeutic effects, particularly those related to inflammation, pain, immunity, and wound healing.

\section{Antibody Production}

It has been demonstrated that honey increased antibody production during primary and secondary immune responses against thymus-dependent and thymus-independent antigens. The actual mechanism to stimulate antibody production was not identified. $\mathrm{NO}$ is an important mediator of immune responses[193]. A single dose of L-arginine, a known precursor of NO, caused a significant increase in humoral response[210]. Therefore, honey might increase humoral immunity by means of its ability to enhance NO production. Prostaglandins are immunosuppressive; they are found to inhibit antibody production by B lymphocytes and to increase the induction of T suppressor cells[201,202]. As honey lowers prostaglandin concentrations, the enhancing effect of honey on antibody production was suggested to be attributed to its ability to inhibit prostaglandins[208]. 


\section{Nutritional Composition}

Honey contains defined substances, such as glucose, fructose, sucrose, minerals, vitamins, antioxidants, amino acids, and other products. Its wide range of activity raised the possibility of the presence of other unidentified substances. The composition with the natural proportion of each substance in the honey might play a significant role in the mechanism of its action and potency. More investigations are needed in order to disclose the possible presence of other natural materials in honey that might play a role in exhibition of its wide biological and therapeutic effects.

\section{Wound Contracture}

In Nigeria, dressing wounds of rats with honey significantly enhanced percentage wound contraction on day 10 with a value of $79.20 \pm 2.94$ compared to the control value of $53.50 \pm 4.32$. There was no significant difference in fibroblast count per high power field in the honey group compared to the control group. In addition, honey dressing increased mean blood vessel count per high power field. Also, honey dressing caused increased granulation tissue formation in wounds compared to those of the control group[211].

\section{CONCLUSION}

There are tremendous data supporting the effectiveness of honey in the management of wounds. The data clearly demonstrate that with the use of honey, no allergic reaction is elicited and no significant side effects were reported, and there is rapid elimination of wound odor, improvement of granulation and epithelialization, reduction of amount of exudates, and sterilization of wounds from microbes. In addition to its valuable nutritional constituents, honey has anti-inflammatory and antioxidant activities that make it a suitable natural subject for wound healing. Honey increases NO, which is important for wound healing, and decreases prostaglandins, which are mediators of inflammation. Honey's acidity and osmolarity play an important role in the healing process. Its antioxidant contents are important as wound healers and help in the eradication of microbial infections. In addition, honey has considerable effects on the cellular elements of immunity and antibody production. Although most studies on honey did not mention its plant source, honeys collected from various geographical areas share a similar ability to help both wound healing and microbial control.

The antibacterial, anti-inflammatory, antioxidant, as well as nutritional and physical properties of honey, make it a logical and accepted natural agent for wound dressing.

\section{REFERENCES}

1. Brigham, P.A. and McLoughlin, E. (1996) Burn incidence and medical care use in the United States: estimate, trends, and data sources. J. Burn Care Rehabil. 17, 95-107.

2. Heldin, C. and Westermark, B. (1996) Role of platelet-derived growth factor in vivo. In The Molecular and Cellular Biology of Wound Repair. 2nd ed. Clark, R.A.F., Ed. Plenum Press, New York. pp. 249-273.

3. Leibovich, S. and Ross, R. (1975) The role of the macrophage in wound repair: a study with hydrocortisone and antimacrophage serum. Am. J. Pathol. 78, 71-100.

4. AL-Waili, N. (1989) Peritoneal macrophages transfusion in the treatment of chronic postoperative wound infections. J. Pak. Med. Assoc. 39, 310-312.

5. Clark, R., Nielsen, L., Welch, M., and McPherson, J. (1995) Collagen matrices attenuate the collagen-synthetic response of cultured fibroblasts to TGF- $\beta$. J. Cell Sci. 108, 1251-1261.

6. Welch, M., Odland, G., and Clark, R. (1990) Temporal relationships of F-actin bundle formation, collagen and fibronectin matrix assembly, and fibronectin receptor expression to wound contraction. J. Cell Biol. 110, 133-145. 
7. Ilan, N., Mahooti, S., and Madri, J. (1998) Distinct signal transduction pathways are utilized during the tube formation and survival phases of in vitro angiogenesis. J. Cell Sci. 111, 3621-3631.

8. Pipelzadeh, M. and Naylor, I. (1998) The in vitro enhancement of rat myofibroblast contractility by alterations to the pH of the physiological solution. Eur. J. Pharmacol. 357, 257-260.

9. Kaplan, B., Gonul, B., Dincer, S., Dincer Kaya, F., and Babul, A. (2004) Relationships between tensile strength, ascorbic acid, hydroxyproline, and zinc levels of rabbit full-thickness incision wound healing. Surg. Today 34, 747751.

10. MacKay, D. and Miller, A.L. (2003) Nutritional support for wound healing. Altern. Med. Rev. 8, 359-377.

11. Russell, L. (2001) The importance of patients' nutritional status in wound healing. Br. J. Nurs. 10(6 Suppl), S42, S44-49.

12. Dissemond, J., Goos, M., and Wagner, S. (2002) The role of oxidative stress in the pathogenesis and therapy of chronic wounds. Hautarzt 53, 718-723.

13. Scholl, D. and Langkamp-Henken, B. (2001) Nutrient recommendations for wound healing. J. Intraven. Nurs. 24, 124-132.

14. Jagetia, G., Rajanikant, G., Baliga, M., Rao, K., and Kumar, P. (2004) Augmentation of wound healing by ascorbic acid treatment in mice exposed to gamma-radiation. Int. J. Radiat. Biol. 80, 347-354.

15. Rasik, A.M. and Shukla, A. (2000) Antioxidant status in delayed healing type of wounds. Int. J. Exp. Pathol. 81, 257263.

16. Dominguez-Rosales, J., Mavi, G., Levenson, S., and Rojkind, M. (2000) H(2)O(2) is an important mediator of physiological and pathological healing responses. Arch. Med. Res. 31, 15-20.

17. Duda, D., Fukumura, D., and Jain, R. (2004) Role of eNOS in neovascularization: NO for endothelial progenitor cells. Trends Mol. Med. 10, 143-145.

18. Kirk, S., Hurson, M., Regan, M., Holt, D., Wasserhrug, H., and Barbul, A. (1993) Arginine stimulates wound healing and immune function in elderly human beings. Surgery 114, 155-160.

19. Weller, R., Ormerod, A., Hobson, R., and Benjamin, N. (1998) A randomised trial of acidified nitrite cream in the treatment of Tinea pedis. J. Am. Acad. Dermatol. 38, 559-563.

20. Dykhuizen, R., Frazer, C., and Duncan, C. (1996) Anti-microbial effects of acidified nitrite on gut pathogens: importance of dietary nitrite in host defence. Antimicrob. Agents Chemother. 40, 1442-1445.

21. Kaplan, S., Lancaster, J., Basford, R., and Simmons, R. (1996) Effect of nitric oxide on staphylococcus killing and interactive effect with superoxide infection. Infect. Immun. 64, 69-76.

22. Bulgrin, J., Shabani, M., Chakravarthy, D., and Smith, D. (1995) Nitric oxide synthesis is depressed in steroid impaired and diabetic wounds. Wounds 7, 48-57.

23. Schaeffer, M., Tantry, U., Efron, P., Ahrendt, G., Thornton, F., and Barbul, A. (1997) Diabetes-impaired wound healing and reduced wound nitric oxide synthesis: a possible pathophysiological correlation. Surgery 121, 513-519.

24. McGrath, M. (1982) The effect of prostaglandin inhibitors on wound contraction and the myofibroblast. Plast. Reconstr. Surg. 69, 74-85.

25. Bennett, L., Rosenblum, R., Perlov, C., Davidson, J., Barton, R., and Nanney, L. (2001) An in vivo comparison of topical agents on wound repair. Plast. Reconstr. Surg. 108, 675-687.

26. Nakae, H. and Inaba, H. (2000) Electrolyzed strong acid aqueous solution irrigation promotes wound healing in a burn wound model. Artif. Organs 24, 544-546.

27. Majno, G. (1975) The Healing Hand. Man and Wound in the Ancient World. Harvard University Press, Cambridge, MA. pp. 571.

Banby, M. (1988) Healing effect of floral honey from sugar-fed bee, on surgical wounds (animal model). In Proceedings of the 4th International Conference on Apiculture in Tropical Climates, Cairo, November 6-10. International Bee Research Association, Cardiff, U.K. pp. 46-49. Kaegi, C. (1995) Honey for healing. Schweitz. Bienen-Zeitung 118, 590-592.

30. Topham, J. (2002) Why do some cavity wounds treated with honey or sugar paste heal with scarring? J. Wound Care $11,53-55$.

31. Oryan, A. and Zaker, S. (1998) Effects of topical application of honey on cutaneous wound healing in rabbits. J. Vet. Med. A 45, 181-188.

32. Oladejo, O., Imosemi, I., Osuagwu, F., Oyedele, O., Oluwadara, O., Ekpo, O., Aiku, A., Adewoyin, O., and Akang, E. (2003) A comparative study of the wound healing properties of honey and Ageratum conyzoides. Afr. J. Med. Med. Sci. 32, 193-196.

33. Hejase, M., Bihrle, R., and Coogan, C. (1996) Genital Fournier's gangrene: experience with 38 patients. Urology 47, 734-739.

34. Yang, K. (1944) The use of honey in the treatment of chilblains, non-specific ulcers, and small wounds. Chin. Med. J. 62, 55-60.

35. Hutton, D. (1966) Treatment of pressure sores. Nurs. Times 62, 1533-1534.

36. Weber, H. (1937) Honig zur Behandlung vereiterter Wunden. Ther. Ggw. 78, 547.

37. Iftikhar, F., Arshad, M., Rasheed, F., Amraiz, D., Anwar, P., and Gulfraz, M. (2010) Effects of acacia honey on wound healing in various rat models. Phytother. Res. 24(4), 583-586. 
38. Subrahmanyam, M. (1998) A prospective randomized clinical and histological study of superficial burn wound healing with honey and silver sulfadiazine. Burns 24, 157-161.

39. Kumar, A., Sharma, V., Singh, H., Prakash, P., and Singh, S. (1993) Efficacy of some indigenous drugs in tissue repair in buffaloes. Indian Vet. J. 70, 42-44.

40. Gupta, S., Singh, H., Varshney, A., and Prakash, P. (1992) Therapeutic efficacy of honey in infected wounds in buffaloes. Indian J. Anim. Sci. 62, 521-523.

41. Bulman, M. (1955) Honey as a surgical dressing. Middlesex Hosp. J. 55, 188-189.

42. Suguna, L., Chandrakasan, G., and Joseph, K.T. (1992) Influence of honey on collagen metabolism during wound healing in rats. J. Clin. Biochem. Nutr. 13, 7-12.

43. Bergman, A., Yanai, J., Weiss, J., Bell, D., and David, M. (1983) Acceleration of wound healing by topical application of honey. An animal model. Am. J. Surg. 145, 374-376.

44. Aysan, E., Ayar, E., Aren, A., and Cifter, C. (2002) The role of intra-peritoneal honey administration in preventing post-operative peritoneal adhesion. Eur. J. Obstet. Gynecol. Reprod. Biol. 104, 152-155.

45.

Mertz, P. and Ovington, L. (1993) Wound healing microbiology. Dermatol. Clin. 11, 739-747.

47. of healing. Diagn. Microbiol. Infect. Dis. 5, 31-38.

48.

49.

Teng, P., Falanga, V., and Kerdel, F. (1993) The microbiological evaluation of ulcers and infected dermatoses in patients requiring hospitalization. Wounds 5, 133-136.

Kontianen, S. and Rinne, E. (1988) Bacteria in ulcera crurcum. Acta Dermatol. Vernerol. 68, 240-244.

Lawrence, J. and Bottone, E. (1951) Pseudomonas aeruginosa pyocyanea in burns. Lancet ii, 137-147.

Mitchell, A. and Pettigrew, J. (1970) Varicose ulcers as reservoirs of hospital strains of Staphylococcus aureus and Pseudomonas pyocyanea. Br. J. Clin. Pract. 24, 223-226.

51. Gilliand, E., Dore, C., and Natchwani, N. (1988) Bacterial colonization of leg ulcers and its effects on the success rate of skin grafting. Ann. R. Coll. Surg. Engl. 70, 105-108.

52.

53. Bowler, P. (2002) Wound pathophysiology, infection and therapeutic options. Ann. Med. 34, 419-427.

Bose, B. (1983) Honey or sugar in the treatment of infected wounds. Lancet 1(8278), 963.

54. Bayisaba, G., Bazira, L., Habonimana, E., and Muteganya, D. (1993) Clinical and bacteriological results in wounds treated with honey. J. Orthop. Surg. 7, 202-204.

55.

56.

57.

58.

Forrest, R. (1982) Early history of wound treatment. J. R. Soc. Med. 75, 198-205.

Molan, P. (1999) Why honey is effective as a medicine: 1. Its use in modern medicine. Bee World 80, 80-92.

Molan, P. (1999) The role of honey in wound care. J. Wound Care 8(8), 415-418.

Jull, A.B., Rodgers, A., and Walker, N. (2008) Honey as a topical treatment for wounds. Cochrane Database Syst. Rev. (4), CD005083.

59. Sharp, A. (2009) Beneficial effects of honey dressings in wound management. Nurs. Stand. 24(7), 66-68.

60. Ousey, K. and McIntosh, C. (2009) Topical antimicrobial agents for the treatment of chronic wounds. Br. $J$. Community Nurs. 14(9), S6, S8, S10 passim.

61. Pieper, B. (2009) Honey-based dressings and wound care: an option for care in the United States. J. Wound Ostomy Continence Nurs. 36(1), 60-66.

62. Molan, P.C. (2001) Potential of honey in the treatment of wounds and burns. Am. J. Clin. Dermatol. 2(1), 13-19.

63. Molan, P.C. (2006) The evidence supporting the use of honey as a wound dressing. Int. J. Low Extrem. Wounds 5(1), 40-54.

64. Moghazy, A.M., Shams, M.E., Adly, O.A., Abbas, A.H., El-Badawy, M.A., Elsakka, D.M., Hassan, S.A., Abdelmohsen, W.S., Ali, O.S., and Mohamed, B.A. (2010) The clinical and cost effectiveness of bee honey dressing in the treatment of diabetic foot ulcers. Diabetes Res. Clin. Pract. 89(3), 276-281.

65. Misirlioglu, A., Eroglu, S., Karacaoglan, N., and Akan, M. (2003) Use of honey as an adjunct in the healing of splitthickness skin graft donor site. Dermatol. Surg. 29, 168-172.

66. Ayyildiz, A., Akgül, K.T., Cebeci, O., Nuhoğlu, B., Caydere, M., Ustün, H., and Germiyanoğlu, C. (2007) Intraurethral honey application for urethral injury: an experimental study. Int. Urol. Nephrol. 39(3), 815-821.

67. Al-Waili, N. (2004) Investigating the antimicrobial activity of natural honey and its effects on the pathogenic bacterial infections of surgical wounds and conjunctiva. J. Med. Food 7, 210-222.

68. Al-Waili, N. and Saloom, K. (1999) Effects of topical honey on post-operative wound infections due to gram positive and gram negative bacteria following caesarean sections and hysterectomies. Eur. J. Med. Res. 4, 126-130.

69. Phuapradit, W. and Saropala, N. (1992) Topical application of honey in treatment of abdominal wound disruption. Aust. N. Z. J. Obstet. Gynaecol. 32(4), 381-384.

70. Vardi, A., Barzilay, Z., Linder, N., Cohen, H.A., Paret, G., and Barzilai, A. (1998) Local application of honey for treatment of neonatal postoperative wound infection. Acta Paediatr. 87, 429-432.

71. Khanal, B., Baliga, M., and Uppal, N. (2010) Effect of topical honey on limitation of radiation-induced oral mucositis: an intervention study. Int. J. Oral Maxillofac. Surg. 39(12), 1181-1185.

72. 200-204. 
74. Oluwatosin, O.M., Olabanji, J.K., Oluwatosin, O.A., Tijani, L.A., and Onyechi, H.U. (2000) A comparison of topical honey and phenytoin in the treatment of chronic leg ulcers. Afr. J. Med. Sci. 29(1), 31-34.

75. Ndayisaba, G., Bazira, L., and Habonimana, E. (1992) Treatment of wounds with honey. 40 cases. Presse Med. 21, 1516-1518.

76. Mphande, A.N., Killowe, C., Phalira, S., Jones, H.W., and Harrison, W.J. (2007) Effects of honey and sugar dressings on wound healing. J. Wound Care 16(7), 317-319.

77. Tshukudu, G.M., van der Walt, M., and Wessels, Q. (2010) Comparative in vitro study of honey based and silver based wound preparations on cell viability. Burns 36(7), 1036-1041.

78. Du Toit, D.F. and Page, B.J. (2009) An in vitro evaluation of the cell toxicity of honey and silver dressings. J. Wound Care 18(9), 383-389.

79. Ingle, R., Levin, J., and Polinder, K. (2006) Wound healing with honey--a randomised controlled trial. S. Afr. Med. J. 96(9), 831-835.

80. Merckoll, P., Jonassen, T.Ø., Vad, M.E., Jeansson, S.L., and Melby, K.K. (2009) Bacteria, biofilm and honey: a study of the effects of honey on 'planktonic' and biofilm-embedded chronic wound bacteria. Scand. J. Infect. Dis. 41(5), 341-347.

81. Gethin, G.T., Cowman, S., and Conroy, R.M. (2008) The impact of Manuka honey dressings on the surface pH of chronic wounds. Int. Wound J. 5(2), 185-194.

82. Ndayisaba, G., Bazira, L., Habonimana, E., and Muteganya, D. (1993) Clinical and bacteriological outcome of wounds treated with honey. J. Orthop. Surg. 7, 202-204.

83. Rudzka-Nowak, A., Łuczywek, P., Gajos, M.J., and Piechota, M. (2010) Application of manuka honey and GENADYNE A4 negative pressure wound therapy system in a 55-year-old woman with extensive phlegmonous and necrotic lesions in the abdominal integuments and lumbar region after traumatic rupture of the colon. Med. Sci. Monit. 16, CS138-142.

84. Blaser, G., Santos, K., Bode, U., Vetter, H., and Simon, A. (2007) Effect of medical honey on wounds colonised or infected with MRSA. J. Wound Care 16(8), 325-328.

85. Visavadia, B.G., Honeysett, J., and Danford, M.H. (2008) Manuka honey dressing: an effective treatment for chronic wound infections. Br. J. Oral Maxillofac. Surg. 46(1), 55-56.

86. McIntosh, C.D. and Thomson, C.E. (2006) Honey dressing versus paraffin tulle gras following toenail surgery. $J$. Wound Care 15(3), 133-136.

87. Hon, J. (2005) Using honey to heal a chronic wound in a patient with epidermolysis bullosa. Br. J. Nurs. $14(19$ Suppl), S4-S12.

88. Robson, V., Dodd, S., and Thomas, S. (2009) Standardized antibacterial honey (Medihoney) with standard therapy in wound care: randomized clinical trial. J. Adv. Nurs. 65(3), 565-575.

89. Dunford, C., Cooper, R., and Molan, P. (2000) Using honey as a dressing for infected skin lesions. Nurs. Times Plus 96, 7-9.

90. Natarajan, S., Williamason, D., and Grey, J. (2001) Healing of an MRSA-colonized, hydroxyurea-induced leg ulcer with honey. J. Dermatolog. Treat. 12, 33-36.

91. Ahmed, A.K., Hoekstra, M.J., Hage, J.J., and Karim, R.B. (2003) Honey-medicated dressing: transformation of an ancient remedy into modern therapy. Ann. Plast. Surg. 50(2), 143-147; discussion 147-148.

92. Bittmann, S., Luchter, E., Thiel, M., Kameda, G., Hanano, R., and Längler, A. (2010) Does honey have a role in paediatric wound management? Br. J. Nurs. 19(15), 19-24.

93. Molan, P. (1998) A brief review of honey as a clinical dressing. Prim. Intent. 6, 137-158.

94. $\quad$ Blomfield, R. (1973) Honey for decubitus ulcers. JAMA 22, 905.

95. Mutalik, S. (1991) Comment: the use of honey and sugar for the treatment of ulcers in leprosy. Lepr. Rev. 62, 228.

96. Tosson, Z., Rashed, A., and Hegazi, A.G. (1997) Honey and propolis as management of chronic skin ulcers. The International Symposium on Apitherapy, Cairo, March 8-9.

97. Samper, R., Pineiro,P., Caballero, M., Ramos, J., Cuza, A., and Rivera, G. (1997) Two decubitus ulcer patients in critical situation treated with honey and propolis (honey with propolis mixture, HPM, used to treat burns). In the XXXV-Th. Apimondia Congress, Antwerp, Belgium.

98. Somerfield, S. (1991) Honey and healing. J. R. Soc. Med. 84(3), 179.

99. $\quad$ Bloomfield, E. (1976) Old remedies. J. R. Coll. Gene Pract. 26, 576.

100. Van der Weyden, A. (2003) The use of honey for the treatment of two patients with pressure ulcers. Br. J. Community Nurs. 8, S14-20.

101. Mossel, D. (1980) Honey for necrotic breast ulcers. Lancet 2, 1091.

102. Tovey, F. (1991) Honey and healing. J. R. Soc. Med. 84, 447.

103. Eddy, J.J., Gideonsen, M.D., and Mack, G.P. (2008) Practical considerations of using topical honey for neuropathic diabetic foot ulcers: a review. WMJ 107(4), 187-190.

104. Sare, J.L. (2008) Leg ulcer management with topical medical honey. Br. J. Community Nurs. 13(9), S22, S24, S26 passim.

105. Shukrimi, A., Sulaiman, A.R., Halim, A.Y., and Azril, A. (2008) A comparative study between honey and povidone iodine as dressing solution for Wagner type II diabetic foot ulcers. Med. J. Malaysia 63(1), 44-46. 
106. Dunford, C.E. and Hanano, R. (2004) Acceptability to patients of a honey dressing for non-healing venous leg ulcers. J. Wound Care 13(5), 193-197.

107. Gethin, G. and Cowman, S. (2008) Bacteriological changes in sloughy venous leg ulcers treated with manuka honey or hydrogel: an RCT. J. Wound Care 17(6), 241-244, 246-247.

108. Gethin, G. and Cowman, S. (2005) Case series of use of Manuka honey in leg ulceration. Int. Wound J. 2(1), 10-15.

109. Yapucu Güneş, U. and Eşer, I. (2007) Effectiveness of a honey dressing for healing pressure ulcers. J. Wound Ostomy Continence Nurs. 34(2), 184-190.

110. Makhdoom, A., Khan, M.S., Lagahari, M.A., Rahopoto, M.Q., Tahir, S.M., and Siddiqui, K.A. (2009) Management of diabetic foot by natural honey. J. Ayub Med. Coll. Abbottabad. 21(1), 103-105.

111. Jull, A., Walker, N., Parag, V., Molan, P., and Rodgers, A. (2008) Honey as Adjuvant Leg Ulcer Therapy trial collaborators. Randomized clinical trial of honey-impregnated dressings for venous leg ulcers. Br. J. Surg. 95(2), $175-182$.

112. Okany, C.C., Atimomo, C.E., and Akinyanju, O.O. (2004) Efficacy of natural honey in the healing of leg ulcers in sickle cell anaemia. Niger. Postgrad. Med. J. 11(3), 179-181.

113. Subrahmanyam, M. (1991) Topical application of honey in treatment of burns. Br. J. Surg. 78(4), 497-498.

114. Phillips, C. (1933) Honey for burns. Glean. Bee Cult. 61, 284.

115. Boukraâ, L. and Sulaiman, S.A. (2010) Honey use in burn management: potentials and limitations. Forsch. Komplementmed. 17(2), 74-80.

116. Lineen, E. and Namias, N. (2008) Biologic dressing in burns. J. Craniofac. Surg. 19(4), 923-928.

117. Moore, O.A., Smith, L.A., Campbell, F., Seers, K., McQuay, H.J., and Moore, R.A. (2001) Systematic review of the use of honey as a wound dressing. BMC Complement. Altern. Med. 1, 2.

118. Wijesinghe, M., Weatherall, M., Perrin, K., and Beasley, R. (2009) Honey in the treatment of burns: a systematic review and meta-analysis of its efficacy. N. Z. Med. J. 122(1295), 47-60.

119. Burlando, F. (1978) Sull'azione terapeutica del miele nelle ustioni. Minerva Dermatol. 113, 699-706.

120. Postmes, T., Bosch, M., Dutrieux, R., van Baare, J., and Hoekstra, M. (1997) Speeding up the healing of burns with honey. An experimental study with histological assessment of wound biopsies. In Bee Products: Properties, Applications and Apitherapy. Mizrahi, A. and Lensky, Y., Eds. Plenum Press, New York. pp. 27-37.

121. Khoo, Y.T., Halim, A.S., Singh, K.K., and Mohamad, N.A. (2010) Wound contraction effects and antibacterial properties of Tualang honey on full-thickness burn wounds in rats in comparison to hydrofibre. BMC Complement. Altern. Med. 10, 48.

122. Nasir, N.A., Halim, A.S., Singh, K.K., Dorai, A.A., and Haneef, M.N. (2010) Antibacterial properties of tualang honey and its effect in burn wound management: a comparative study. BMC Complement. Altern. Med. 10, 31.

123. Malik, K.I., Malik, M.A., and Aslam, A. (2010) Honey compared with silver sulphadiazine in the treatment of superficial partial-thickness burns. Int. Wound J. 7(5), 413-417.

124. Hashemi, B., Bayat, A., Kazemei, T., and Azarpira, N. (2009) Comparison between topical honey and mafenide acetate in treatment of auricular burn. Am. J. Otolaryngol. 30, 345-349.

125. Emsen, I.M. (2007) A different and safe method of split thickness skin graft fixation: medical honey application. Burns 33(6), 782-787.

126. Subrahmanyam, M. (1994) Honey-impregnated gauze versus amniotic membrane in the treatment of burns. Burns 20(4), 331-333.

127. Baghel, P.S., Shukla, S., Mathur, R.K., and Randa, R. (2009) A comparative study to evaluate the effect of honey dressing and silver sulfadiazene dressing on wound healing in burn patients. Indian J. Plast. Surg. 42(2), 176-181.

128. Subrahmanyam, M. (1993) Honey impregnated gauze versus polyurethane film (OpSite®) in the treatment of burns a prospective randomised study. Br. J. Plast. Surg. 46, 322-323.

129. McInerney, R. (1990) Honey - a remedy rediscovered. J. R. Soc. Med. 83, 127.

130. Zaiß (1934) Der Honig in äußerlicher Anwendung. Muench. Med. Wochenschr. 49, 1891-1893.

131. Keast-Butler, J. (1980) Honey for necrotic malignant breast ulcers. Lancet ii, 809.

132. Green, A. (1988) Wound healing properties of honey. Br. J. Surg. 75, 1278.

133. Molan, P. and Betts, J. (2004) Clinical usage of honey as wound dressing: an update. J. Wound Care 13, $353-356$.

134. Benhanifia, M.B., Boukraâ, L., Hammoudi, S.M., Sulaiman, S.A., and Manivannan, L. (2011) Recent patents on topical application of honey in wound and burn management. Recent Pat. Inflamm. Allergy Drug Discov. 5(1), 81-86.

135.

136.

137.

138. Zumla, A. and Lulat, A (1989) Honey - a remedy rediscovered. J. R. Soc. Med. 82, 384-385.

Molan, P. (2001) Potential of honey in the treatment of wounds and burns. Am. J. Clin. Dermatol. 2(1), 13-19.

Bose, B. (1982) Honey or sugar in treatment of infected wounds? Lancet i, 963.

Dustmann, J.H. (1979) Antibacterial effect of honey. Apiacta 14(1), 7-11.

139. Temnov, V. (1944) Bactericidal properties of honey and utilization of honey and other beekeeping products for the healing of wounds. Bee World 23, 86-87.

140. Adeleye, A. and Opiah, L. (2003) Antimicrobial activity of extract of local cough mixture on upper respiratory tract bacterial pathogens. West Indian Med. J. 52, 188-190.

141. Efem, S., Udoh, K., and Iwara, C. (1992) The antimicrobial spectrum of honey and its clinical significance. Infection 20, 227-229. 
142. Al-Jabri, A.A., Nzeako, B., Al Mahrooqi, Z., Al Naqdy, A., and Nsanze, H. (2003) In vitro antibacterial activity of Omani and African honey. Br. J. Biomed. Sci. 60, 1-4.

143. Cooper, R. and Molan, P. (1999) The use of honey as an antiseptic in managing Pseudomonas infection. J. Wound Care 8, 161-164.

144. Cooper, R., Halas, E., and Molan, P. (2002) The efficacy of honey in inhibiting strains of Pseudomonas aeruginosa from infected burns. J. Burn Care Rehabil. 23, 366-370.

145. Cooper, R., Molan, P., and Harding, K. (1999) Antibacterial activity of honey against strains of Staphylococcus aureus from infected wounds. J. R. Soc. Med. 92, 283-285.

146. Cooper, R., Molan, P., and Harding, K. (2002) The sensitivity to honey of Gram-positive cocci of clinical significance isolated from wounds. J. Appl. Microbiol. 93, 857-863.

147. Allen, K.L., Molan, P.C., and Reid, G.M. (1991) A survey of the antibacterial activity of some New Zealand honeys. J. Pharm. Pharmacol. 43, 817-822.

148. Miorin, P., Levy, N., Jr., Custodio, A., Bretz, W., and Marcucci, M. (2003) Antibacterial activity of honey and propolis from Apis mellifera and Tetragonisca angustula against Staphylococcus aureus. J. Appl. Microbiol. 95, 913920.

149. Osato, M., Reddy, S., and Graham, D. (1999) Osmotic effect of honey on growth and viability of Helicobacter pylori. Dig. Dis. Sci. 44, 462-464.

150. Taormina, P., Niemira, B., and Beuchat, L. (2001) Inhibitory activity of honey against foodborne pathogens as influenced by the presence of hydrogen peroxide and level of antioxidant power. Int. J. Food Microbiol. 69, $217-225$.

151. Farouk, A., Hassen, T., Kashif, H., Khalid, S., Mutawali, I., and Wadi, M. (1988) Studies on Sudanese bee honey: laboratory and clinical evaluation. Int. J. Crude Drug Res. 26, 161-168.

152. Karayil, S., Deshpande, S.D., and Koppikar, G.V. (1998) Effect of honey on multidrug resistant organisms and its synergistic action with three common antibiotics. J. Postgrad. Med. 44, 93-96.

153. Archer, H., Barnett, S., Irving, S., Middleton, K., and Seal, D. (1990) A controlled model of moist wound healing: comparison between semi-permeable film, antiseptics and sugar paste. J. Exp. Pathol. 71, 155-170.

154. Yoo, S.K. and Huttenlocher, A. (2009) Innate immunity: wounds burst H2O2 signals to leukocytes. Curr. Biol. 19(14), R553-555.

155. Cho, M., Hunt, T.K., and Hussain, M.Z. (2001) Hydrogen peroxide stimulates macrophage vascular endothelial growth factor release. Am. J. Physiol. Heart Circ. Physiol. 280, H2357-H2363.

156. White, J., Subers, M., and Schepartz, A. (1963) The identification of inhibine, the antibacterial factor in honey, as hydrogen peroxide and its origin in a honey glucose-oxidase system. Biochem. Biophys. Acta 73, 57-79.

157. Molan, P. (1992) The antibacterial activity of honey. 1. The nature of antibacterial activity. Bee World 73, 5-28.

158. White, J., Subers, M., and Schepartz, A. (1962) The identification of inhibine. Am. Bee J. 102, 430-431.

159. White, J. and Subers, M. (1963) Studies on honey inhibine. 2. A chemical assay. J Apic. Res. 2, 93-100.

160. Schmidt, R., Chung, L., Andrews, A, and Turner, T. (1992) Hydrogen peroxide is a murine (L929) fibroblast cell proliferent at micro- to nanomolar concentrations. Second European Conference on Advances in Wound Management, Harrogate, October 20-23.

161. Molan, P.C. (2001) Honey as a topical antibacterial agent for treatment of infected wounds. http://www.worldwidewounds.com/2001/november/Molan/honey-as-topical-agent.html

162. Bang, L.M., Buntting, C., and Molan, P. (2003) The effect of dilution on the rate of hydrogen peroxide production in honey and its implications for wound healing. J. Altern. Complement. Med. 9, 267-273.

163. Chirife, J. and Scarmato, G. (1982) Scientific basis for use of granulated sugar in treatment of infected wounds. Lancet 1, 560-561.

164. Tur, E., Bolton, L., and Constantine, B. (1995) Topical hydrogen peroxide treatment of ischemic ulcers in the guinea pig: blood recruitment in multiple skin sites. J. Am. Acad. Dermatol. 33(2 Pt 1), 217-221.

165. Frankel, S., Robison, G., and Berenbaum, R. (1998) Antioxidant capacity and correlated characteristic of 14 unifloral honeys. J. Apic. Res. 37, 27-31.

166. Brudzynski, K. (2006) Effect of hydrogen peroxide on antibacterial activities of Canadian honeys. Can. J. Microbiol. 52(12), 1228-1237.

167. Knutson, R., Merbitz, L.A., Creekmore, M., and Snipes, H. (1981) Use of sugar and povidone-iodine to enhance wound healing: five year's experience. South. Med. J. 74, 1329-1335.

168. Condon, R.E. (1993) Curious interaction of bugs and bees. Surgery 113, 234-235.

169. Seymour, F. and West, K. (1951) Honey -- its role in medicine. Med. Times 79, 104-107.

170. Emarah, M. (1982) A clinical study of the topical use of bee honey in the treatment of some occular diseases. Bull. Islamic Med. 2, 422-425.

171. Adcock, D. (1962) The effect of catalase on the inhibine and peroxide values of various honeys. J. Apic. Res. 1, 3840.

172. Bogdanov, S. (1984) Characterisation of antibacterial substances in honey. Lebensm. Wiss. Technol. 17, 74-76.

173. Molan, P. and Russel, K.M. (1988) Non-peroxide antibacterial activity in some New Zealand honeys. J. Apic. Res. 27, 62-67.

174. Saissy, J., Guignard, B., Pats, B., Guiavarch, M., and Rouvier, B. (1995) Pulmonary edema after hydrogen peroxide irrigation of a war wound. Intensive Care Med. 21, 287-288. 
175. Salahudeen, A., Clark, E., and Nath, K. (1991) Hydrogen peroxide-induced renal injury. A protective role for pyruvate in vitro and in vivo. J. Clin. Invest. 88, 1886-1893.

176. Halliwell, B. and Cross, C.E. (1994) Oxygen-derived species: their relation to human disease and environmental stress. Environ. Health Perspect. 102(Suppl 10), 5-12.

177. Floh, L. and Beckmann, R. (1985) Oxygen-centred free radicals as mediators of inflammation. In Oxidative Stress. Sies, H., Ed. Academic Press, London.

178. Tanaka, H. and Hanumadass, M. (1995) Hemodynamic effects of delayed initiation of antioxidant therapy (beginning two hours after burn) in extensive third-degree burn. J. Burn Care Rehabil. 16, 610-615.

179. Bunting, C.M. (2001) The Production of Hydrogen Peroxide by Honey and Its Relevance to Wound Healing [MSc thesis]. University of Waikato, Hillcrest, New Zealand.

180. Tonks, A.J., Cooper, R.A., Jones, K.P., Blair, S., Parton, J., and Tonks, A. (2003) Honey stimulates inflammatory cytokine production from monocytes. Cytokine 21, 242-247.

181. Fukuda, M., Kobayashi, K., Hirono, Y., Miyagawa, M., Ishida, T., Ejiogu, E.C., Sawai, M., Pinkerton, K.E., and Takeuchi, M. (2009) Jungle honey enhances immune function and antitumor activity. Evid. Based Complement. Altern. Med. 6, 50-56.

182. Ryan, G. and Majno, G. (1977) Inflammation. Upjohn Company, Kalamazoo, MI.

183. Zaika, L. (2001) The effect of temperature and low pH on survival of Shigella flexneri in broth. J. Food Prot. 64, $1162-1165$.

184. Castanie-Cornet, M. and Foster, J. (2001) Escherichia coli acid resistance: cAMP receptor protein and a 20 bp cisacting sequence control $\mathrm{pH}$ and stationary phase expression of the gadA and gadBC glutamate decarboxylase genes. Microbiology 147(Pt 3), 709-715.

185. Gock, M.A., Hocking, A.D., Pitt, J.I., and Poulos, P.G. (2003) Influence of temperature, water activity and pH on growth of some xerophilic fungi. Int. J. Food Microbiol. 81, 11-19.

186. Castanie-Cornet, M.-P., Smith, D., Elliott, J., and Foster, J. (1999) Control of acid resistance in Escherichia coli. J. Bacteriol. 181, 3525-3535.

187. Gorden, J. and Small, P. (1993) Acid resistance in enteric bacteria. Infect. Immun. 61, 364-367.

188. Kaufman, T., Eichenlaub, E.H., Angel, M.F., Levin, M., and Futrell, J.W. (1985) Topical acidification promotes healing of experimental deep partial thickness skin burns: a randomized double-blind preliminary study. Burns Incl. Therm. Inj. 12(2), 84-90.

189. Childress, B. and Stechmiller, K. (2002) Role of nitric oxide in wound healing. Biol. Res. Nurs. 4, 5-15.

190. Moncada, S., Palmer, M., and Higgs, A. (1991) Nitric oxide: physiology, pathophysiology and pharmacology. Pharmacol. Rev. 43, 109-142.

191. Schwentker, A., Vodovotz ,Y., and Weller, R. (2002) Nitric oxide and wound repair: role of cytokines. Nitric Oxide 7, $1-10$.

192. Baldik, Y., Talu, U., Altinel, L., and Bilge, H. (2002) Bone healing regulated by nitric oxide: an experimental study in rats. Clin. Orthop. 404, 343-352.

193. Zeidek, Z. and Masek, K. (1998) Erratic behavior of nitric oxide within the immune system: illustrative review of conflicting data and their immunopharmcological aspects. Int. J. Immunopharmacol. 20, 319-343.

194. Koetzler, R., Zaheer, R.S., Newton, R., and Proud, D. (2009) Nitric oxide inhibits IFN regulatory factor 1 and nuclear factor-kappaB pathways in rhinovirus-infected epithelial cells. J. Allergy Clin. Immunol. 124(3), 551-557.

195. Weller, R., Schwentker, A., and Billiar, R. (2003) Autologous nitric oxide protects mouse and human keratinocytes from ultraviolet B radiation-induced apoptosis. Am. J. Physiol. Cell Physiol. 284, C1140-C1148.

196. Al-Waili, N. (2003) Identification of nitric oxide metabolites in various honeys: effects of intravenous honey on plasma and urinary nitric oxide metabolites concentrations. J. Med. Food 6, 359-364.

197. AL-Waili, N. and Saleeb, N. (2003) Honey increased nitric oxide end product in saliva of healthy volunteer. FASEB Conference, San Diego, April 11-15. Abstr. 236.

198. AL-Waili, N. (2004) Honey increased saliva, plasma, and urine content of total nitrite concentrations in normal individuals. J. Med. Food 7, 377-380.

199. Molan, P., Smith, L., Campbell, F., and Seers, K. (2001) Systemic review of the use of honey as a wound dressing. BMC Complement. Altern. Med. 1, 2-10.

200. Phipps, R., Stein, S., and Roper, R. (1991) A new view of prostaglandin E regulation of the immune response. Immunol. Today 12, 349-352.

201. Yakar, I., Melamed, R., Shakhar, G., Shakhar, K., Rosenne, E., Abudarham, N., Page, G.G., and Ben-Eliyahu, S. (2003) Prostaglandin e(2) suppresses NK activity in vivo and promotes postoperative tumor metastasis in rats. Ann. Surg. Oncol. 10(4), 469-479.

202. Kozlov, V., Poveschenko, A., and Gromyhina, N. (1990) Some mechanism involved in the prostaglandin E2 immunosuppressive effect in F1 mice in vivo. Cell. Immunol. 128, 242-249.

203. Fischer, S. (2002) Is cyclooxygenase-2 important in skin carcinogenesis? J. Environ. Pathol. Toxicol. Oncol. 21, 183191.

204. Al-Waili, N. (1989) Indomethacin in basal cell carcinoma. J. Pak. Med. Assoc. 39, 134-136.

205. Al-Waili, N., Al-Azzawi, H., and Al-Rawi, Z, (1984) Treatment of advanced chorionic carcinoma by indomethacin and steroids. Saudi Med. J. 5, 81-88. 
206. Al-Waili, N., Thewani, A., and Al-Azzawi, H. (1980) The effects of PGA1 on antibody production. The World Conference on Clinical Pharmacology and Therapeutics, London, Aug. 3-9.

207. Al-Azzawi, H., Al-Waili, N., Thewani, A., and Al-Samarrai, H. (1981) The effects of PGAl on serum protein components during primary and secondary immune responses. J. Fac. Med. Bagh. 23, 54.

208. AL-Waili, N. and Boni, N. (2003) Natural honey lowers plasma prostaglandin concentrations in normal individuals. $J$. Med. Food 6, 129-133.

209. AL-Waili, N. (2005) Effect of honey on urinary excretion of prostaglandin and nitric oxide urinary nitrite. Int. Urol. Nephrol. 37(1), 107-111.

210. Sunita, R., Goutam, R., Mishra, S., and Ravi, P. (2000) Role of nitric oxide in central regulation of humoral immune response in rats. Indian J. Pharmacol. 32, 318-320.

211. Osuagwu, F.C., Oladejo, O.W., Imosemi, I.O., Aiku, A., Ekpos, O.E., Salami, A.A., Oyedele, O.O., and Akang, E.U. (2004) Enhanced wound contraction in fresh wounds dressed with honey in Wistar rats (Rattus Novergicus). West Afr. J. Med. 23(2), 114-118.

\section{This article should be cited as follows:}

Al-Waili, N.S., Salom, K., and Al-Ghamdi, A.A. (2011) Honey for wound healing, ulcers, and burns; data supporting its use in clinical practice. TheScientificWorldJOURNAL 11, 766-787. DOI 10.1100/tsw.2011.78. 

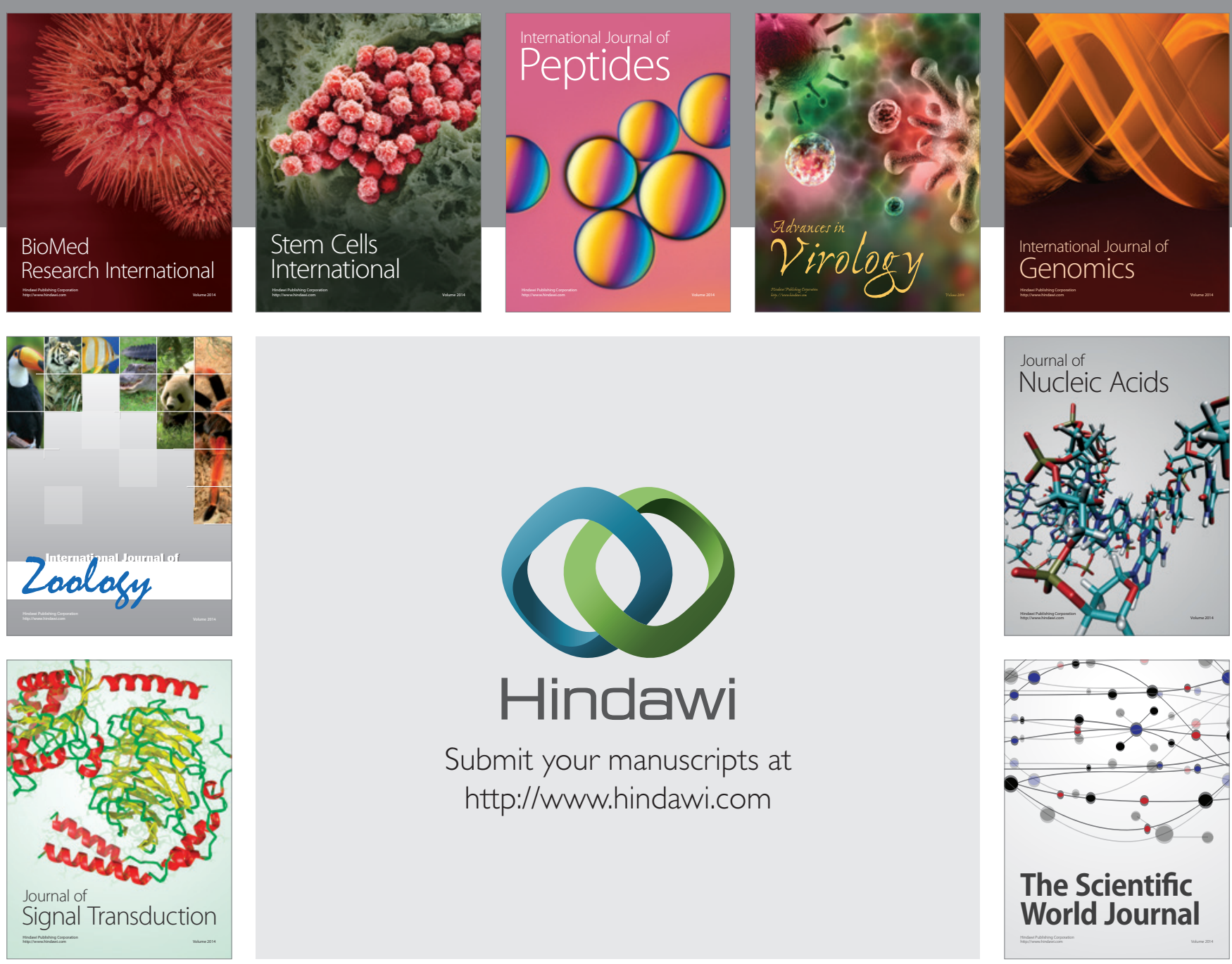

Submit your manuscripts at

http://www.hindawi.com
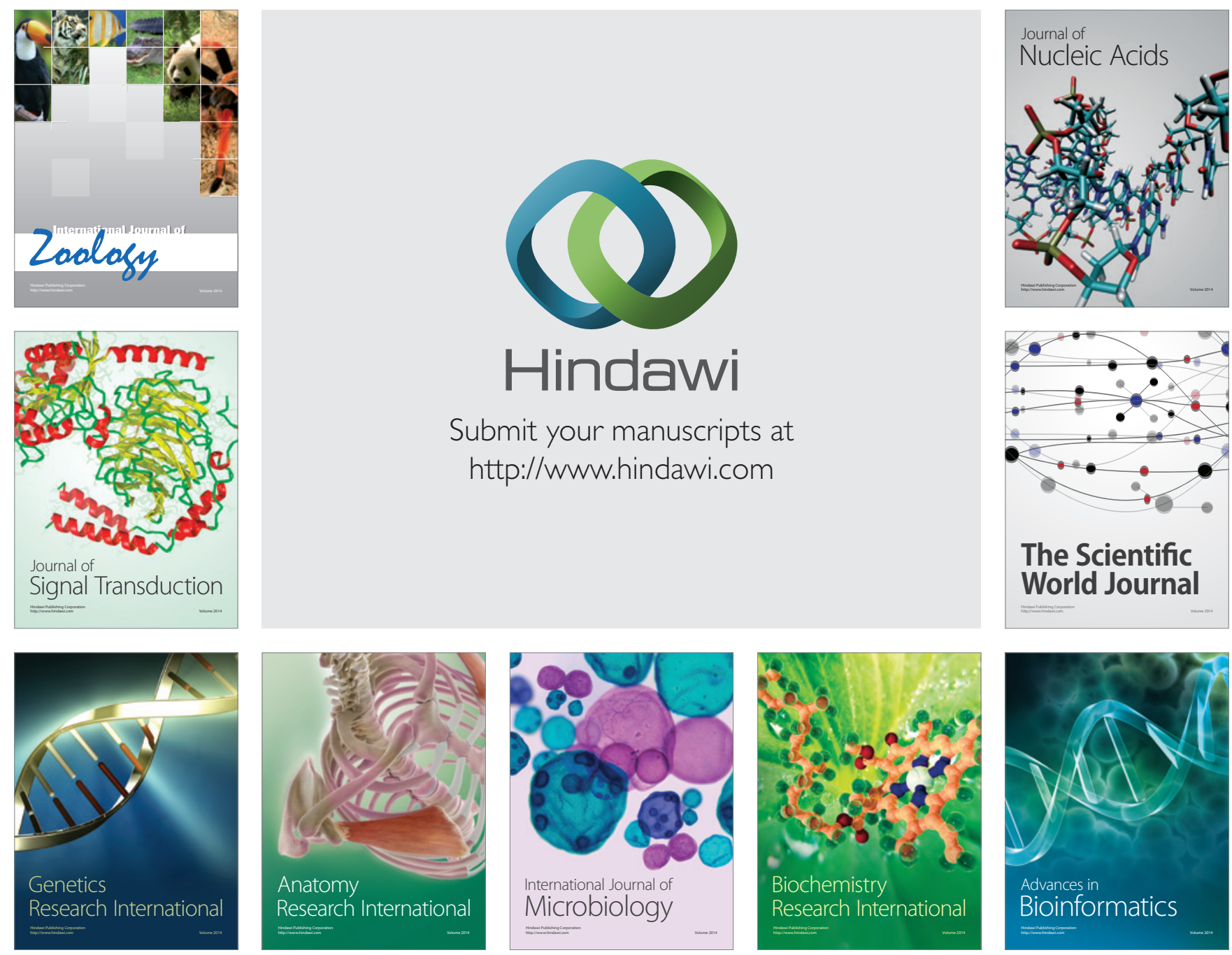

The Scientific World Journal
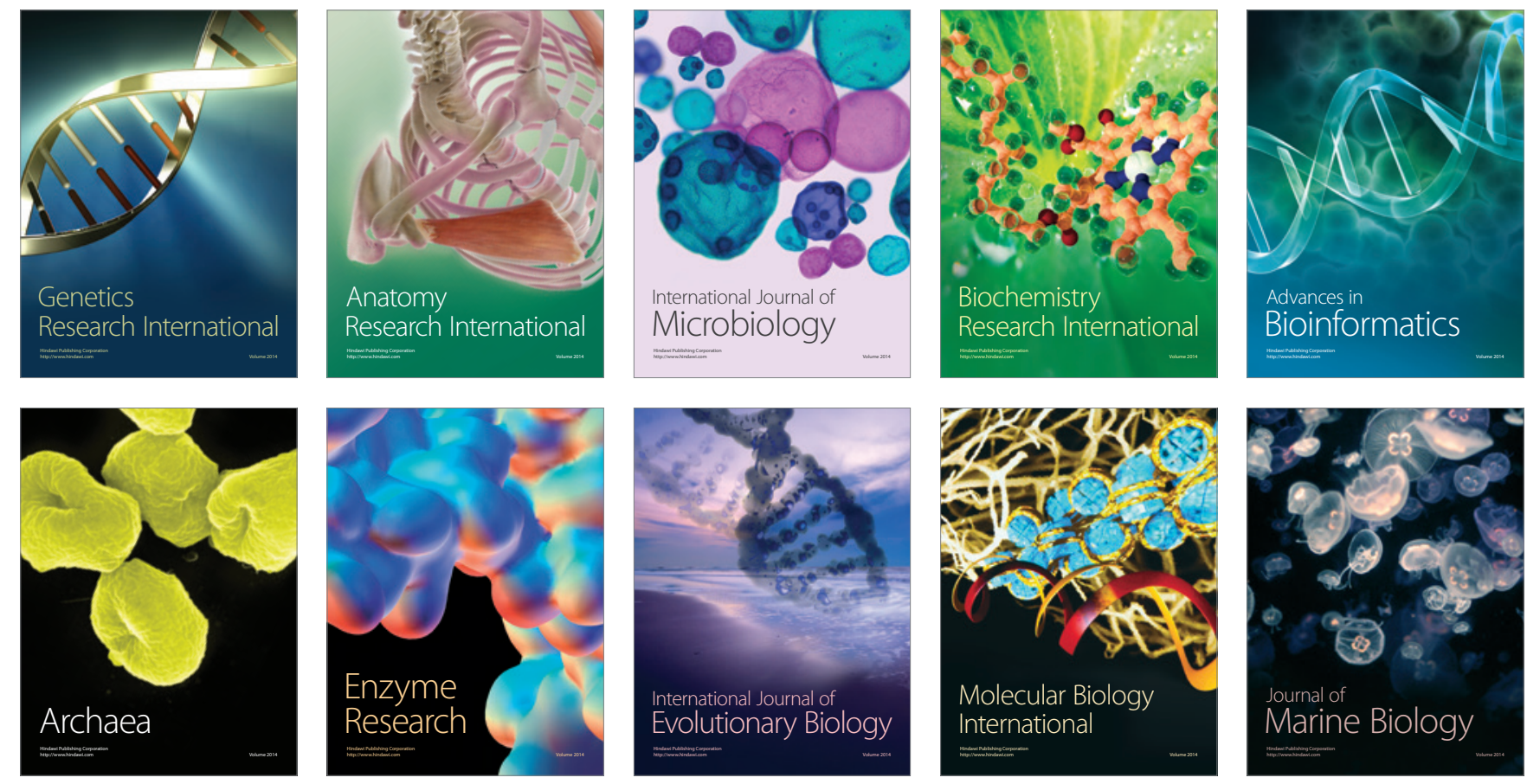